\title{
Fossil associations from the middle and upper Eocene strata of the Pamplona Basin and surrounding areas (Navarre, western Pyrenees)
}

\author{
H. Astibia ${ }^{1 *}$, A. Payros ${ }^{1}$, S. Ortiz², J. Elorza ${ }^{3}$, G. Álvarez-Pérez ${ }^{4}$, A. Badiola ${ }^{1}$, N. Bardet ${ }^{5}$, A. \\ Berreteaga ${ }^{1}$, M.A. Bitner ${ }^{6}$, S. Calzada7, J.C. Corral ${ }^{8}$, I. Díaz-Martínez ${ }^{9}$, D. Merle ${ }^{5}$, J.-M. Pacaud ${ }^{5}$, X. \\ Pereda-Suberbiola ${ }^{1}$, A. Pisera ${ }^{6}$, F.J. Rodríguez-Tovar ${ }^{10}$, J. Tosquella ${ }^{11}$ \\ ${ }^{1}$ Departamento de Estratigrafía y Paleontología, Facultad de Ciencia y Tecnología, Universidad del País Vasco/Euskal Herriko \\ Unibertsitatea (UPV/EHU), Apartado de correos 644, 48080 Bilbao, Spain. \\ ${ }^{2}$ PetroStrat Ltd, Tan-y-Graig, Parc Caer Seion, Conwy, Wales, LL32 8FA, UK. \\ ${ }^{3}$ Departamento de Mineralogía y Petrología, Facultad de Ciencia y Tecnología, Universidad del País Vasco/Euskal Herriko \\ Unibertsitatea (UPV/EHU), Apartado de correos 644, 48080 Bilbao, Spain. \\ ${ }^{4}$ Departament d'Estratigrafia, Paleontologia i Geociències Marines. Universitat de Barcelona. Martí i Franqués s/n. 08028 Barcelona, Spain. \\ ${ }^{5}$ Centre de recherche sur la paléobiodiversité et les paléoenvironnements (CR2P), UMR 7207 du CNRS, Département Histoire de la \\ Terre, Muséum National d'Histoire Naturelle, CP 38, 57 rue Cuvier, 75005 Paris, France. \\ ${ }^{6}$ Institute of Paleobiology, Polish Academy of Sciences, ul. Twarda 51/55, PL-00-818 Warsaw, Poland. \\ ${ }^{7}$ Museu Geòlogic del Seminari de Barcelona. Diputació 231. 08007 Barcelona, Spain. \\ ${ }^{8}$ Arabako Natur Zientzien Museoa/Museo de Ciencias Naturales de Álava, Siervas de Jesús, 01001 Vitoria-Gasteiz, Spain. \\ ${ }^{9}$ CONICET-Instituto de Investigación en Paleobiología y Geología, Universidad Nacional de Río Negro, General Roca 1242,8332 \\ General Roca, Argentina. \\ ${ }^{10}$ Departamento de Estratigrafía y Paleontología, Facultad de Ciencias, Universidad de Granada, Campus Universitario de Fuentenueva \\ $s / n, 18071$ Granada, Spain. \\ ${ }^{11}$ Departamento de Geodinámica y Paleontología, Facultad de Ciencias Experimentales, Campus del Carmen, Universidad de Huelva, \\ Avenida de las Fuerzas Armadas 21071 Huelva, Spain.
}

e-mail addresses: humberto.astibia@ehu.eus (*corresponding author); a.payros@ehu.eus (A.P.); silvia.ortiz@petrostrat.com (S.O.); josejavier. elorza@ehu.es (J.E.); galvarez@xtec.cat (G.A-P.); ainara.badiola@ehu.eus (A.B.); bardet@mnhn.fr (N.B.); ana.berreteaga@ehu.eus (A.B.); bitner@twarda.pan.pl (M.A.B.); almeracomas@hotmail.com (S.C.); jc.corral@arrakis.es (J.C.C.); inaportu@hotmail.com (I.D-M.); dmerle@mnhn. fr (D.M.); pacaud@mnhn.fr (J-M.P); xabier.pereda@ehu.eus (X.P-S.); apis@twarda.pan.pl (A.P.); fjrtovar@ugr.es (F.J.R-T.); josep@uhu.es (J.T.)

Received: 22 December 2015 / Accepted: 13 March 2016 / Available online: 30 April 2016

\begin{abstract}
Fossil associations from the middle and upper Eocene (Bartonian and Priabonian) sedimentary succession of the Pamplona Basin are described. This succession was accumulated in the western part of the South Pyrenean peripheral foreland basin and extends from deep-marine turbiditic (Ezkaba Sandstone Formation) to deltaic (Pamplona Marl, Ardanatz Sandstone and Ilundain Marl formations) and marginal marine deposits (Gendulain Formation). The micropalaeontological content is high. It is dominated by foraminifera, and common ostracods and other microfossils are also present. The fossil ichnoasssemblages include at least 23 ichnogenera and 28 ichnospecies indicative of Nereites, Cruziana, and ?Scoyenia-Mermia ichnofacies. Body macrofossils of about 80 taxa corresponding to macroforaminifera, sponges, corals, bryozoans, brachiopods, annelids, molluses, arthropods, echinoderms and vertebrates have been identified. Both the number of ichnotaxa and of species (e. g. bryozoans, molluscs and condrichthyans) may be considerably higher. Body fossil assemblages are comparable to those from the Eocene of the Nord Pyrenean area (Basque Coast), and also to those from the Eocene of the west-central and eastern part of South Pyrenean area (Aragon and Catalonia). At the European scale, the molluscs assemblages seem endemic from the Pyrenean area, although several Tethyan (Italy and Alps) and Northern elements (Paris Basin and Normandy) have been recorded. Palaeontological data of studied sedimentary units fit well with the shallowing process that throughout the middle and late Eocene occurs in the area, according to the sedimentological and stratigraphical data.
\end{abstract}




\section{Resumen}

Se describen las asociaciones fósiles del Eoceno medio y superior (Bartoniense y Priaboniense) de la sucesión sedimentaria de la Cuenca de Pamplona. Esta sucesión se acumuló en la parte oeste de la Cuenca de antepaís periférica surpirenaica y comprende desde turbiditas marinas profundas (Formación Areniscas de Ezkaba) hasta depósitos deltaicos (Formaciones Margas de Pamplona, Areniscas de Ardanatz y Margas de Ilundain) y marinos marginales (Formación Gendulain). El contenido micropaleontológico es alto y está dominado por los foraminíferos. Los fósiles de ostrácodos y otros organismos son también abundantes. Las asociaciones de icnofósiles incluyen al menos 23 icnogéneros y 28 ichnoespecies, indicativas de las icnofacies de Nereites, Cruziana, y ?Scoyenia-Mermia. Se han identificado fósiles corporales de unos 80 taxones, correspondientes a macroforaminíferos, esponjas, corales, briozoos, braquiópodos, anélidos, moluscos, artrópodos, equinodermos y vertebrados. El número de icnotaxones y de especies (p. e. briozoos, moluscos gasterópodos, bivalvos y peces condríctios) puede ser considerablemente mayor. Las asociaciones de fósiles corporales son comparables a las del Eoceno del Área norpirenaica (Costa vasca) y de las partes central y este del Área surpirenaica (Aragón y Cataluña). A escala europea, la asociación de moluscos parece endémica del Área pirenaica, aunque contiene elementos del Tetis (Italia y Alpes) y de las cuencas del norte (Cuenca de París y Normandía). El contenido paleontológico de las unidades sedimentarias analizadas es coherente con el proceso de somerización que tiene lugar a lo largo del Eoceno medio y tardío, de acuerdo con lo que indican los datos sedimentológicos y estratigráficos.

Palabras clave: Asociaciones fósiles, Paleógeno, turbiditas, delta, marino somero, Cuenca Surpirenaica

\section{Introduction}

The current biogeographic distribution of species shows the existence of hotspots characterized by high biodiversity. In marine areas the highest biodiversity is centered in the so-called Indo-Australian Archipelago hotspot. According to Renema et al. (2008), this hotspot was preceded by at least two other marine biodiversity hotspots during the past 50 million years: the Early Miocene hotspot, centered at the Arabian region, and the Eocene hotspot, which was located in the West Tethyan region.

Near the West Tethyan region, in the Atlantic area, the marine fauna of the middle Eocene of the Paris Basin showed an extraordinary biodiversity during Lutetian times and can be regarded as an extension of the West Tethyan hotspot (Merle, 2008; Merle et al., 2008; Huyghe et al., 2012). Merle (2008, 2009) indicates the presence of species of Tethyan origin in the Paris Basin, which contributed to enrich the biodiversity of this region. During Bartonian, the Eastern Atlantic marine biodiversity fell, but the Paris Basin and the Loire-Atlantique (Britain) still correspond to very rich areas having a mollusc richness exceeding 1000 species (Merle, 2008; 2009, Lebrun et al., 2013). It is during the Priabonian when the biodiversity decreased significantly in both sides of the Atlantic Ocean.

Because of its paleogeographic position, the Pyrenean area could have played an important role as an Eocene paleobiogeographical crossover between the Tethyan and Northern Atlantic domains. Although Rouault (1850), Doncieux (1908) and Cossmann and O'Gorman (1923) described rich marine faunas from the early Eocene of Pau and the Corbières, the Pyrenean marine faunas from the middle/late Eocene are still poorly documented. In the North Pyrenean area, the classical works made by d'Archiac (1846, 1850), de Bouillé (1873, 1876), Boussac (1911) about the "Nummulitic" of the Basque Coast, have hardly been updated. In Aragon and Catalonia (South Pyrenean area) the works of Villalta (1956), De Renzi (1971, 1996), Abad (2001), Pisera and Busquets (2002), among others, on fossil molluscs and sponges, can be mentioned.

The Pamplona Basin is located to the south of the Basque Coast and to the west of Aragon and Catalonia. However, from a palaeontological point of view, the Pamplona Basin is less known than its neighbouring areas. The first data were published by the French geologist Carez (1881). For this author, the Pamplona marls (Pamplona Marl Formation) were identical to the "marls of Serpula spirulaea", which were continuations of the La Canal de Berdún marls (Zaragoza, Aragon). Many years later, Ruiz de Gaona (1947) and Ruiz de Gaona and Colom (1950) completed a more comprehensive study of these formations, describing their foraminiferal content and concluding that they were Bartonian in age. These authors also mentioned the occurrence of important macrofossil associations near the city of Pamplona. Local micropaleontological determinations were carried out later by Puigdefábregas (1975) and Alameda et al. (1993). Macropalaeontological works on the bivalve Dimya pamplonensis (Calzada and Astibia, 1996), turtles and sirenians (Astibia et al., 1999; 2005; 2006; Buffrénil et al., 2008), and sponges and corals (Astibia et al., 2014) have been published in the latest years. Avian ichnofossils from the Gendulain Formation were cited and described in Mangin (1959-1960), Raaf et al. (1965), Payros et al. (2000), Astibia et al. (2007), and Astibia et al. (in press).

The aim of this paper is to present updated data about the fossil associations from the Pamplona Basin, which includes new information on fossil molluscs. The results will further contribute to enlarge the database for a better understanding of the evolution of global marine biodiversity throughout the Eocene.

\section{Geological setting}

The study area is located in the central part of Navarre (South-western Pyrenees). The current distribution and characteristics of the Eocene rocks in the area show the geometry and evolution of the original sedimentary basin (Fig. 1; see Pujalte et al., 2002). In Eocene times, the South Pyrenean zone was a NW-trending foreland basin which formed adjacent to the tectonically uplifting orogen to the north. It remained as a narrow strip of sea entering from the Bay of Biscay at approximately $35^{\circ} \mathrm{N}$ palaeolatitude, but its palaeogeography changed in response to the increasing tectonic de- 

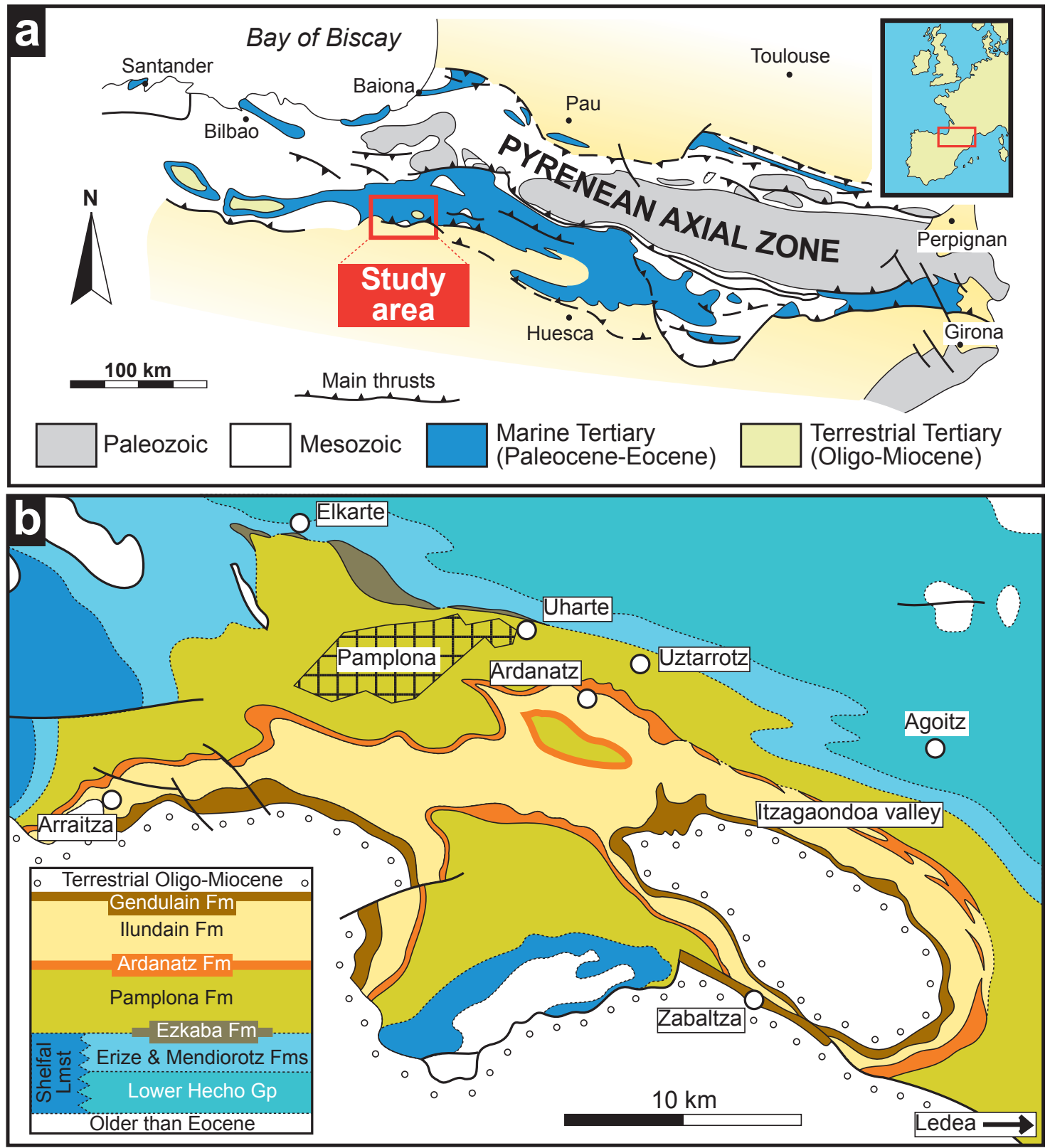

Fig. 1.- Simplified geological maps of the Pyrenees (a), with location of the study area in the western part of the South Pyrenean Zone (SPZ), and of the Pamplona Basin and nearby areas (b).

formation. During early-middle Eocene (Ypresian-Lutetian) times the basin was essentially a deep-water trough, but siliciclastic sediments derived from the uplifting and denuding Pyrenees progressively filled the basin in. The main denudation area was first located in the emergent eastern Pyrenees, where large fluviodeltaic systems developed. However, this palaeogeographic configuration progressively encroached westwards, so that by middle-late Eocene (Bartonian-Priabonian) times denudation of the orogen began in the western Pyrenees and the fluviodeltaic sedimentary context became widespread throughout the foreland basin (Plaziat, 1981; Pujalte et al., 2002; Barnolas et al., 2004).

The later stage is well recorded in the central part of $\mathrm{Na}$ varre by alternating marly and sandy lithostratigraphic units (Fig. 2). The oldest Bartonian units (Erize Marl Formation,
Ezkaba Sandstone Formation and Pamplona Marl Formation) still show sedimentological and palaeontological evidence of accumulation in relatively deep waters, and they were attributed to slope (Payros et al., 2010), turbiditic channel-levee (Payros et al., 1997) and prodelta (Astibia et al., 2005) environments, respectively. The overlying Ardanatz Sandstone Formation (also referred to as Gazolaz, Tajonar, Tabar and/or Gongolaz sandstone in the regional literature) has been thoroughly studied by Astibia et al. (1999, 2005, 2006, 2014). Silty marls are dominant in the locality of Ardanatz (central part of the study area), but they contain abundant tabular sandstone beds, which display sharp bases with occasional groove casts (indicating ENE palaeocurrent direction) and gradational upper boundaries; they are rich in carbonaceous plant remains, vertical and horizontal burrows (mainly Ophi- 


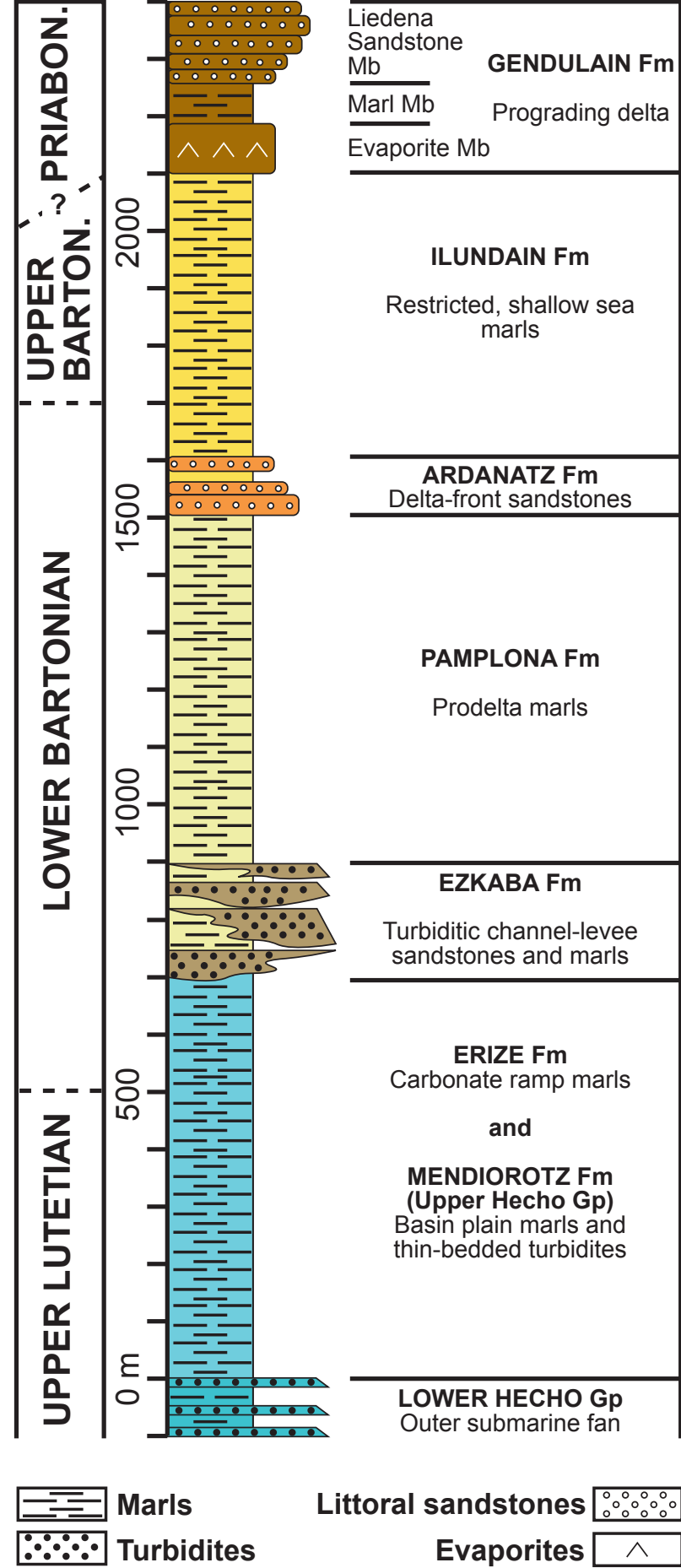

Fig. 2.- Representative columnar section of the middle and upper Eocene marly succession in the Pamplona Basin (Navarre, western Pyrenees), with its constituent lithostratigraphic units and the depositional environments so far proposed in the literature.

omorphids, sensu Seilacher, 2007) and bioclasts (e.g. corals and nummulitids). On the basis of their sedimentological features, the sandstone beds were interpreted as deposits from non-confined, high-concentration turbulent flows. Given that the sandstone beds are arranged in several thickening and coarsening-upward sequences, they were further interpreted as sandy hyperpycnites accumulated in flood-generated delta- front lobes (sensu Mutti et al., 2000; 2003). In Arraitza (western part of the study area; Fig. 1b), the Ardanatz Sandstone is typified by thinner and finer-grained sandstone beds, suggesting a distal or marginal area of the Ardanatz delta front. The Ardanatz Sandstone can also be traced further to the east, bordering the Itzaga syncline, where it shows different sedimentological features (Fig. 1b). Here, laminated sandstone beds, which are normally graded and contain abundant mud clasts, are restricted to large-scale, lens-shaped lithosomes. According to these features, they were interpreted as Northwestward-directed turbiditic channels (Puigdefábregas, 1975; Leon Chirinos, 1985). However, from the general palaeogeographic layout outlined above, it is more likely that these features constituted delta-front channels across which fluvially-derived hyperpycnal flows entered the sea and eventually fed the flood-generated delta-front lobes.

The Ardanatz Sandstone Formation interfingers both laterally and vertically with the Ilundain Marl Formation (Astibia et al., 2014; Fig. 2). In Arraitza, the Ilundain Marl Formation is characterized by thick tabular levels of alternating dark and light grey marls with gradational boundaries. Their siliciclastic content mainly consists of clay, whereas the carbonate content mainly derives from the abundant calcareous skeletal remains, such as bryozoans and others. The fine-grained nature of the sediment, the absence of gravity-flow deposits and the absence of light-dependant organisms suggest that the marls accumulated in a flat, aphotic seabed located below stormwave base. This interpretation is further supported by the microforaminiferal content, similarly as common hexactinellid sponges and their preservation, which is indicative of outerplatform to upper-slope environments (Astibia et al., 2014).

The Eocene succession is topped by the Priabonian Gendulain Formation (Puigdefábregas, 1975), which is composed of different types of coastal deposits, allowing its subdivision into three distinct members: lower evaporites, middle marls, and upper sandstones (Liédena Sandstone Member) (Fig. 2). Lateral variations in facies and thicknesses record the synsedimentary tectonic deformation of the study area (Cendon et al., 1998; Payros et al., 2000), as it progressively became a detached piggy-back basin atop of southward displacing thrust sheets. Owing to the concomitant tectonic uplift, the Gendulain Formation records the last episode of deltaic progradation from the ESE, the closure of the South Pyrenean Sea, and its definite evolution into terrestrial conditions.

\section{Material and methods}

The studied fossils were mainly collected from several outcrops located between the towns of Uharte and Elkarte (Ezkaba Sandstone Formation), from the localities of Uztarrotz (Eguesibar, base of the Pamplona Marl Formation), Ardanatz-Eguesibar (transition from the Ardanatz Sandstone Formation to the overlying Ilundain Marl Formation), Arraitza (approximately $100 \mathrm{~m}$ above the base of the Ilundain Marl Formation), from two outcrops in the Itzagaondoa Valley 
(in the uppermost part of the Ilundain Marl Formation), and from five outcrops between the towns of Zabaltza and Ledea-Liédena (Liédena Sandstone Member of the Gendulain Formation) (Fig. 1b). Precise locations of outcrops are not given for the protection of the fossil sites in accordance with Natural and Cultural Heritage legislation. Those who want to know further details are asked to contact the corresponding author.

A semi-quantitative study of foraminifera was carried out on two outcrops of the base of the Pamplona Marl Formation (Uztarrotz) and the uppermost part of the Ilundain Formation (Itzagaondoa Valley). These micropalaeontological data are added to those made in Arraitza (level ARR1.1), in Ardanatz (levels AD2.1 and AD3.1), and in the Liédena Sandstone (Liédena and other localities, facies B1, B3 and B4) (in Payros et al., 2000; Astibia et al., 2014).

Most of the collected fossils are provisionally deposited in the Department of Stratigraphy and Palaeontology of the University of the Basque Country (Universidad del País Vasco/Euskal Herriko Unibertsitatea, UPV/EHU). A few fossils from the locality of Arraitza are housed in the Museo de Ciencias Naturales de Álava/ Arabako Natur Zientzien Museoa (MCNA) of Vitoria-Gasteiz. Most trace fossils have been photographed and studied initially in the field and only a few samples have been collected and taken to the laboratory (UPV/EHU).

\section{Taphonomic remarks}

The Bartonian deposits of the study area are very rich in microfossils, but not in body macrofossils, which are only locally abundant. Ichnofossils are very abundant, mainly in sandy units and marls with high terrigenous content. In Ardanatz AD3 and Arraitza ARR1 sections fossils of sponges and erected bryozoans are abundant within the silty marls (Astibia et al., 2014). They usually present intense fragmentation, but often seem to correspond to complete or nearly complete specimens, without evidence of abrasion (Fig. $3 a, b)$. From a palaeoecological point of view, they probably correspond to demic organisms, dwellers of relatively deep environments and autochthonous or parautochthonous taphonomic elements (sensu Fernández López, 1990; 1991), deposited during periods of reduced sedimentation in a lowenergy environment. On the contrary, in several outcrops of the Ardanatz Sandstone fossils of nummulitids, corals, and many molluscs are associated mainly with levels of high terrigenous content and may have undergone taphonomic remotion processes (sensu Fernández López, 2000) (Fig. 3c, d).

Epibionts (small bivalves, annelid tubes and encrusting bryozoan colonies) on sponges, corals and shells of molluscs, as well as bioerosion (mainly bryozoan borings) on corals and mollusks, are frequent (Astibia et al., 2014). Peripheral zone of alteration with tunnel network structures, probably made by microbial activity, are observed in thin sections of fossil sirenian ribs (Astibia et al., 2005). Microfossils are often filled with pyrite. Body macrofossils are generally fragmentary, with evidence of dissolution and replacement by calcite and celestite in sponges, dissolution and aragonite-calcite neomorfism processes in corals and molluscs, and replacement by well crystallized francolite (carbonate-fluorapatite) in fossil vertebrates (Astibia et al., 2005; 2014) (Fig. 3e, f). Celestite may form as a result of a rapid decomposition of organic matter in a dysoxic microenvironment that produces hydrogen sulfide. The latter can be oxidized to sulfate by subsequent bacterial sulfoxidation, and this sulfate produces celestite with the mobile strontium, the latter coming either from the aragonite-to-calcite neomorphism (Taberner et al., 2002), or from other processes, such as decomposition of inherited sheet silicate mineral of continental origin with a decreaseacidification of the $\mathrm{pH}$ (Baker and Bloomer, 1988).

Microbial mats impressions have been identified as wrinkle marks preserved in ripple troughs and as retracted zones in the digit impressions of some bird tracks of the Liédena Sandstone (Gendulain Formation) (Fig. 3g,h) (Astibia et al., in press). Microbial mats can greatly enhance the preservation of surface traces (i.e., Marty et al., 2009; Carmona et al., 2012). The reducing chemical conditions beneath the microbial mats may have contributed to the formation of "anoxic" minerals, such as pyrite (Schieber, 1999, 2002), which has also been observed in the surface of some slabs of the Liédena Sandstone. These anoxic conditions could explain the scarcity and low diversity of invertebrate traces in the Liédena Sandstone. According to Carmona et al. (2012), the microbial mats acted as taphonomic bias favouring the preservation of vertebrate tracks and conditioning the presence of endofauna.

\section{Fossil assemblages}

This section describes the different fossil assemblages in relation to the respective lithologic units. All the taxa and ichnotaxa recorded in the study area can be consulted in Appendix I.

\subsection{Ezkaba Sandstone Formation}

Only some microfossils and ichnofossils have been determined so far in this formation. Body macrofossils are scarce and fragmentary and mainly consist of tests of macroforaminifers and spines of echinoids not yet studied.

The marly deposits of the Ezkaba Formation are rich in fossils of planktic foraminifera. Among them Orbulinoides beckmanni, the index species that defines the biozone E12, was identified for the first time in the Pyrenean Domain (Payros et al., 1997). Ichnofossils are very abundant in sandstones. The identified ichnoassemblage includes the ichnotaxa Belorhaphe isp., Ophiomorpha annulata, Ophiomorpha rudis, Phymatoderma isp., Pilichnus dichotomus, Planolites isp., Scolizia strozzii, and Scolizia vertebralis (Fig. 4a, c) (Astibia et al., in press). 

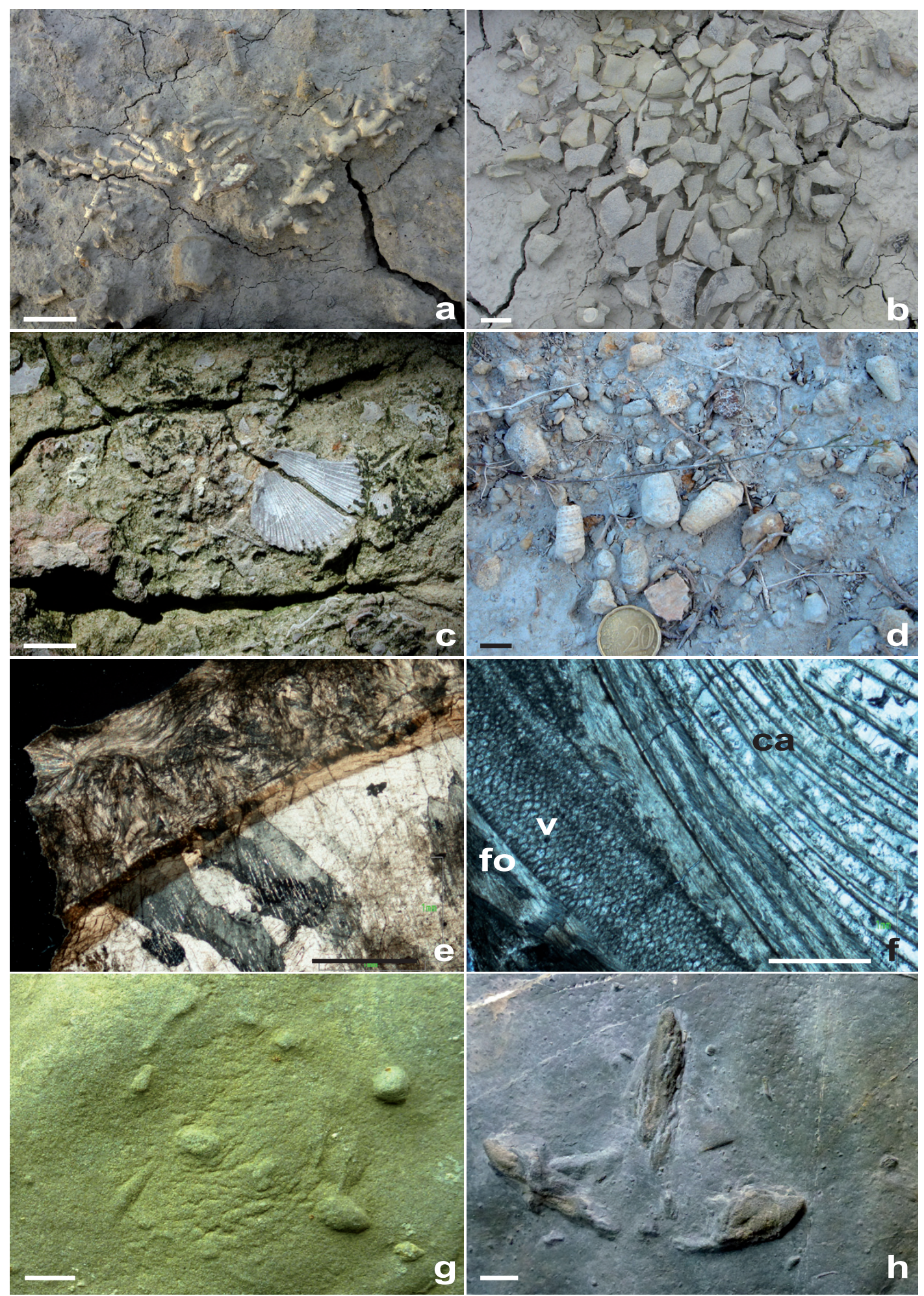

Fig. 3.- Field photographs of fossils from the middle Eocene (Bartonian) of the Ardanatz Sandstone (a, c, d) and Ilundain Marl (b) formations: a, colony of erect bryozoans in the silty marls showing intense fragmentation; $\mathbf{b}$, hexactinellid sponge showing intense fragmentation (modified from Astibia et al., 2014); c, fragmentary shells of the bivalve Chlamys sp. (Cl) and foraminifera tests (operculiniform nummulitids of Assilina genus and others) in a sandstone bed; $\mathbf{d}$, fragmentary and partially dissolved specimens of gastropods [Ptychocerithium johannae (Tournouër in Bouillé, 1873) mainly] in marls with high terrigenous content (sandy marls). Photomicrographies of fossils from Ardanatz Sandstone (e) and Ilundain Marl (f) formations: e, longitudinal thin-section of a specimen of Spondylus sp., with the original prismatic microstructure completely neomorphized by big spatic calcite crystals; $\mathbf{f}$, tangential thin-section of a specimen of Pycnodonte brongniarti (Bronn, 1831), showing foliated (fo) and vesicular (v) microstructures and cementation by calcite in the empty chambers (ca). Ichnofossils from the upper Eocene (Priabonian) of the Liédena Sandstone Member (Gendulain Formation): g, microbial mat impression (wrinkle marks) in ripple troughs and vertical tubes; $\mathbf{h}$, microbial mat impression as retracted zones in a bird track of cf. Leptoptilostipus (Liédena-Ledea section). Scale bars of a, b, $\mathbf{c}, \mathbf{d}, \mathbf{g}, \mathbf{h} 10 \mathrm{~mm}$; scale bars e, f $1 \mathrm{~mm}$. 
In the Elkarte outcrop, a marly stretch with thin interbedded turbidites, there is a predominance of ophiomorphids and graphogliptids. The determined ichnotaxa are: Chondrites isp., Helminthoraphe flexuosa, Multina minima, Nereites irregularis, Ophiomorpha annulata, Ophiomorpha rudis, $\mathrm{Pa}$ leodictyon strozzii, Planolites isp., ?Squamodictyon isp., and Taenidium crassum (Fig. 4b) (Astibia et al., in press).

\subsection{Pamplona Marl Formation}

Pamplona marls are rich in microfossils but the macrofauna is poor. In the Uztarrotz outcrop, an exposure in the lower part of this unit, the microassemblages are dominated by foraminifera which are associated whit common gastropods, serpulids, echinoid spines and smooth-valved ostracods. Benthic foraminifera are abundant and well preserved. Planktic foraminifera dominate the assemblages, the planktic/benthic $(\mathrm{P} / \mathrm{B})$ ratio being $75 \%$. As for the benthic foraminiferal test composition, hyaline taxa dominate the assemblages $(66 \%)$, agglutinated taxa are abundant (33\%), and porcelaneous taxa are very scarce $(<1 \%)$. The benthic foraminiferal assemblages are diverse (around 72 species), slightly dominated by infaunal taxa (57\%). Eponides, Cibicidoides, Lenticulina, Uvigerina, Globobulimina species and nodosariids are the most common hyaline taxa, including Eponides ouachitaensis. The agglutinated taxa are dominated by trochamminids, astrorhizids (Bathysiphon species), Ammobaculites and Marssonella species.

Stem fragments of large isocrinid crinoids (Isselicrinidae: Isselicrinus sp.) are quite common throughout the lower part of the Pamplona Marl Formation. In Uztarrotz, postcranial elements of sirenian mammals have described as Dugongidae indet. (Astibia et al., 2006) (Fig. 5a-g). A few spines of echinoids have also been found there. In the east of the study area ichnofossils of Thalassinoides suevicus are observed in the thin sandy layers interspersed in the marls. Towards the top of the Pamplona Formation trace fossils of Ophiomorpha and Chondrites among others are common.

\subsection{Ardanatz Sandstone Formation}

This unit and the overlying Ilundain Marl Formation have yielded the richest concentrations of body macrofossils. The fossiliferous sites occur at the transition from the Ardanatz Sandstone Formation to the overlying Ilundain Marl Formation. In the Ardanatz outcrops the micropalaeontological content is high in the intercalate marls, being dominated by foraminifera with scarce ostracods and charophyte gyrogonites (Astibia et al., 2014). Benthic foraminifera strongly dominate the assemblages, the $\mathrm{P} / \mathrm{B}$ ratio being $15 \%$ and $5 \%$, respectively. Most benthic foraminifera correspond to hyaline taxa (up to $77 \%$ ). Agglutinated taxa are common and porcelaneous taxa are less common. Benthic foraminiferal assemblages are moderately diverse (about 50 species), with similar proportions of epifaunal and infaunal taxa. The most common hyaline taxa are cibicidids, including Cibicides tenuimago, Cibicides lobatulus and Cibicides refulgens. Other benthic species present in the associations belong to Eponides, Cibicidoides, Oridorsalis and Gyroidinoides genera. Nodosariids are represented by Anomalinoides, Siphonina and Bulimina. The most common agglutinated taxa are calcareous-cemented taxa, including Gaudryina abuillonensis and Spiroplectammina alansis. Trochamminids and Ammobaculites species are common (Astibia et al., 2014).

The result of the study of nummulitids provided an association formed by the species Nummulites aff. cyrenaicus (precursor form), $N$. cf. beaumonti, N. ptukhiani, N. praegarnieri, Assilina schwageri, and Heterostegina reticulata cf. multifida in the locality of Ardanatz; $N$. aff. biedai (precursor form), $N$. cf. perforatus, and $N$. aff. cyrenaicus in the term of Zizari-Ezkoritz; and $N$. aff. biedai and $N$. aff. cyrenaicus in the term of Lezaun (Ardanatz-Eguesibar). All these nummulitid associations characterize the top of the shallow benthic foraminiferal biozone SBZ 17 of Serra-Kiel et al. (1998), corresponding to the lower Bartonian (Astibia et al., 1999).

In the Ardanatz outcrops body macrofossils are locally abundant. The macrofauna is mainly represented by hexactinellid and lithistid sponges, scleractinian corals, bryozoans, brachiopods, tube-dwelling polychaetes, molluscs (gastropods, bivalves, cephalopods -nautiloids- and scaphopods), arthropods (crab claw fragments), echinoderms (crinoid stalk fragments, plates -ossicles- of asteroids, and spines and test fragments of echinoids), shark teeth, turtle plates, as well as sirenian vertebrae and ribs (Figs. 5h-t, $6 \mathrm{a}-\mathrm{k})$. Sponges and corals have been described in Astibia et al. (2014). Among the former there are Laocoetis samueli, Guettardiscyphia thiolati and/or Pleuroguettardia iberica, cf. Rhizocheton robustus, and one indeterminate lithistid (Fig. $5 \mathrm{~h}-\mathrm{j}$ ). Corals are represented by Stylocoenia taurinensis, Astrocoenia octopartita, Ceratotrochus bodellei, Placosmiliopsis bilobatus and Desmophyllum castellolense (Fig. 5k-m). Among bryozoans there are representatives of the Stenolaemata Lichenoporidae, Gymnolaemata Cupuladriidae and numerous erect forms, which are locally very abundant and well-preserved, but not yet studied (Figs. 3a, 5n). Micromorphic brachiopods (Terebratulina tenuistriata) are abundant in marly levels of the lower part of studied sections (Fig. $5 \mathrm{o}, \mathrm{p})$. Among the annelids, the polychaete Rotularia spirulaea is very abundant, being one of the most characteristic macrofossils of the middle and upper parts of the prospected sections (Fig. 5q). Scarce remains of vertebrates, including turtles and sirenians, have been assigned to indeterminate chelonians and dugongids, respectively (Astibia et al., 1999; 2005; 2006; Buffrénil et al., 2008) (Fig. 5t).

With the exception of a brief note on Dimya pamplonensis (Calzada and Astibia, 1996) nothing has been published to date about the fossil molluscs. A study on the molluscs (Gastropoda and Bivalvia) is ongoing. The gastropod association contains the following taxa: Leptomaria peresii, Ptychocerithium johannae, Diastoma costellatum, Haustator 

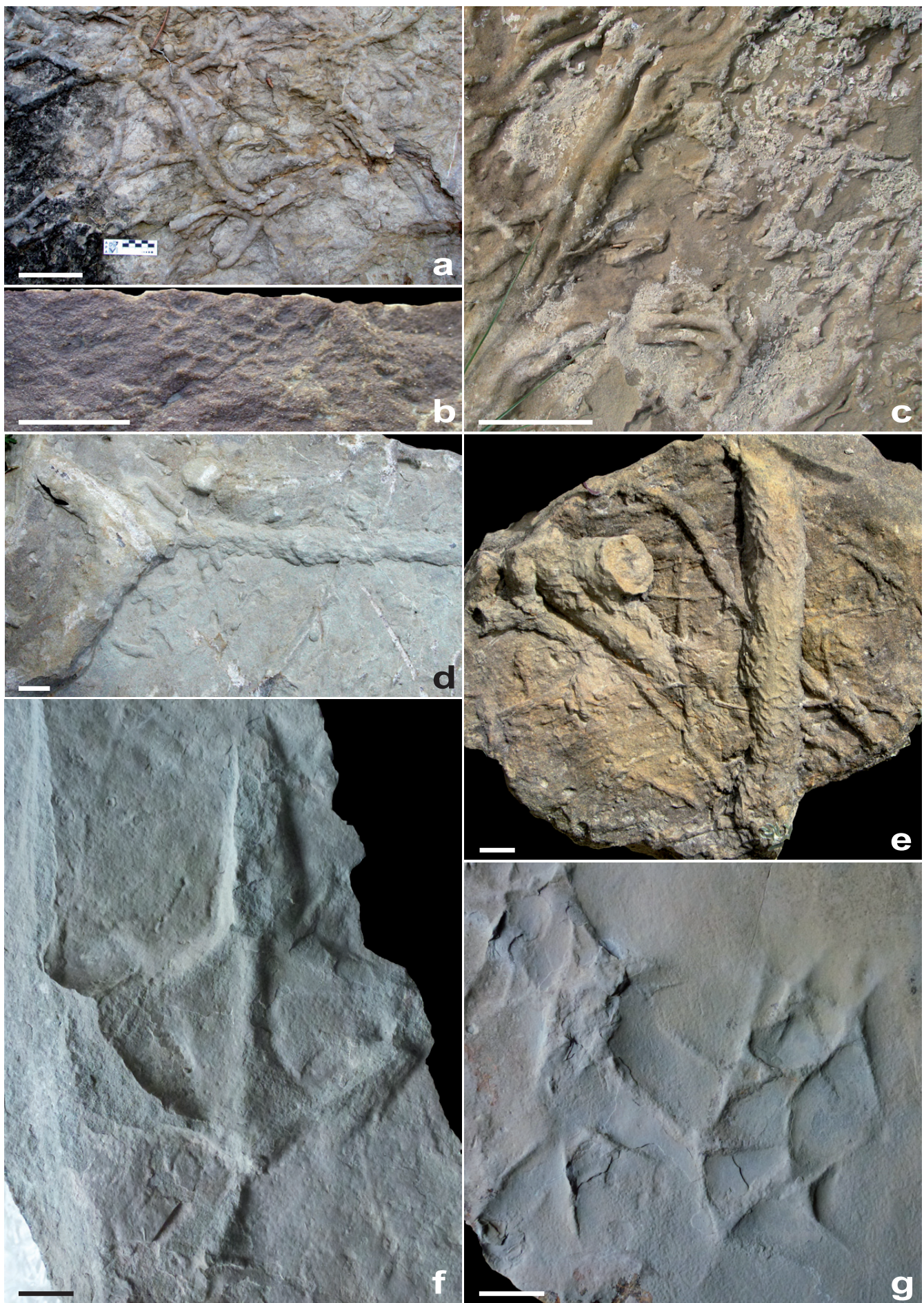

Fig. 4.- Trace fossils from the middle Eocene (Bartonian) of the Ezkaba Formation: a, Ophiomorpha rudis (Książkiewicz, 1977), epichnia; b, Paleodictyon strozzii Meneghini in Savi and Meneghini, 1850, hypichnion; c, Scolicia strozzii (Savi and Meneghini, 1850), hypichnion. Trace fossils from the middle Eocene (Bartonian) of Ardanatz Sandstone-Ilundain Marl formations: d, Ophiomorpha isp., hypichnion; e, Spongeliomorpha cf. oraviense, hypichnia. Trace fossils from the upper Eocene (Priabonian) of Liédena Sandstone (Gendulain Formation): f, J1, Leptoptilostipus pyrenaicus Payros, Astibia, Cearreta, Pereda-Suberbiola, Murelaga and Badiola, 2000, hypichnion.g, LH2, Koreanaornis isp., hypichnia. All the traces are preserved in sandstone beds. Modified from Astibia et al. (in press). Scale bars of a, c $100 \mathrm{~mm}$; scale bars of b, d, e, f, g $10 \mathrm{~mm}$.

altavillensis, Haustator cf. imbricatarius conoideus, Sigmesalia sp., Ampullinidae indet., ?Globularia sp., Cirsotrema (Elegantiscala) cf. bouillei, Amaea sp., Clavilithes (Clavellofusus) cf. parisiensis, Muricidae indet., Athleta (Volutospina) sp., Conidae indet., and Nihonia aff. transversaria (Figs. 3d, 6a-e). Ptychocerithium johannae is by far the most abundant species in the macrogastropod association. The provisional list of bivalves is as follows: Hyotissa martinsi, Ostreoidea indet., Chlamys cf. biarritzensis, Chlamys sp., Spondylus cf. bifrons, Spondylus cf. caldesensis, Spondylus sp., Dimya 
pamplonensis, Chama pellati and Chama granulosa (Figs. 3c,e, $6 \mathrm{f}-\mathrm{h}$ ). Fossil scaphopods (Dentalium sp.) are abundant (Fig. 6i). Finally, rare cephalopods (Nautilolidea indet.) also occur (Fig. 6j, k).

The fossil ichnoassemblages of the Ardanatz Sandstone are dominated by ophiomorphids (sensu Seilacher, 2007), with abundance of the ichnospecies Ophiomorpha nodosa. Other ichnotaxa present, decreasing in abundance, are Ophiomorpha isp., Thalassinoides isp, Spongeliomorpha cf. oraviense, and Halopoa imbricata (Fig. 4d, e) (Astibia et al., in press).

\subsection{Ilundain Marl Formation}

At the west end of the study area, located approximately 100 $\mathrm{m}$ above the base of the Ilundain Formation, are the Arraitza outcrops (Fig. 1b). The microfossils are characterized by the abundance, good preservation and dominance of benthic foraminifera. Planktic foraminifera are scarce (P/B ratio 28\%) and show low diversity; they are strongly dominated by chiloguembelinid taxa. As for the benthic foraminifera, hyaline taxa dominate the assemblages (80\%), agglutinated taxa are common, and porcelaneous taxa are rare. The benthic foraminiferal assemblages are diverse (average 90 species), with similar proportions of infaunal and epifaunal taxa. Cibicidoides, Eponides, cibicidids, elongate uniserial taxa (nodosariids and stilostomellids), and buliminids are the most common hyaline taxa, and include Cibicidoides ungerianus, Eponides ouachitaensis and Cibicides lobatulus. The agglutinated taxa are dominated by trochamminids; the most characteristic are the tubular forms (Bathysiphon) (Astibia et al., 2014).

The body macrofossil assemblages from Arraitza include numerous fossils of the sponges Laocoetis samueli, cf. Rhizocheton robustus, cf. Phlyctia expansa, and two undeterminated lithistids (Fig. 3b). Further components of the association are undetermined corals (scarce), Lichenoporidae and other bryozoans, the brachiopods Terebratulina tenuistriata and ?Gryphus sp., the polychaete Rotularia spirulaea (rare), the bivalves Spondylus cf. bifrons, Dimya pamplonensis and indeterminate ostreoids, the barnacle Arcoscalpellum sp., echinoid spines and test fragments (Cidaridae and others), asteroid ossicles, and the chondrichthyans Hexanchus agassizi, Macrorhizodus praecursor, Anomotodon sp. and Woellsteinia kozlovi. Teleostean teeth (Enchodus sp.) and otoliths (Chaetodipterus sp. and others) are also common among the fossils of Arraitza (Fig. 5u-z).

In the uppermost part of the Ilundain Formation, towards the eastern part of the study area, in the Itzagaondoa Valley, the fossil association changes significantly. The microassemblage is dominated by foraminifera with common ostracods. The foraminifers are abundant and benthic foraminifera strongly dominate the assemblages, the $\mathrm{P} / \mathrm{B}$ ratio being $11 \%$. As for the benthic foraminifers, hyaline taxa dominate the assemblages (50\%), agglutinated taxa are abundant (38\%), and porcelaneous taxa are common (12\%). Benthic foraminiferal are moderately diverse (around 41 species), with similar pro- portions of epifaunal and infaunal taxa. The most common hyaline taxa are Cibicidoides and Planulina species, and Marginulina behmi. The most common agglutinated taxa are calcareous-cemented taxa such as Ammobaculites pyrenaicus and Textularia species; rzehakinids are also common.

Macrofauna in the Itzagaondoa outcrops includes fossils of solitary corals (Ceratotrochus bodellei and others), bryozoans (Gymnolemata Cupuladriidae and erected forms), micromorphic brachiopods (Argyrotheca michelottina), tubedwelling polychaetes (Rotularia spirulaea and others), and mollusc bivalves, gastropods and scaphopods. The mollusc assemblage includes the gastropods Ptychocerithium johannae, Diastoma costellatum, Moniquia sp., Haustator altavillensis, Haustator cf. imbricatarius conoideus, Sigmesalia sp., Sassia sp., Niso sp., Metula (Celatoconus) sp., Clavilithes (Clavellofusus) cf. parisiensis, Muricidae indet., Athleta (Volutospina) sp., Conidae indet. and Mathilda sp., among others (Fig. 61-p). Diastoma costellatum and Haustator cf. imbricatarius conoideus are the most abundant macrogastropods. The provisional list of bivalves of the Itzagaondoa outcrops is as follow: Glycymeris jacquoti, Pycnodonte brongniarti, Chlamys sp., Spondylus sp. cf. S. cisalpinus-S. nysti, Spondylus planicostatus, Venericardia junctinova and Chama pellati. (Figs. 5f, 6q-v). Fossils of these taxa, except perhaps Spondylus planicostatus, which is common, are numerous. Scaphopods are also abundant.

As in the Ardanatz Sandstone unit, the ichnological analysis of the sandy levels intercalated in the lower part of the Ilundain marls shows abundant ophiomorphids, especially Ophiomorpha isp. (aff. O. nodosa-O. irregulaire). Other ichnotaxa found are Halopoa imbricata, Planolites isp., Spongeliomorpha cf. oraviense, Spongeliomorpha cf. sicula, and Thalassinoides isp., together with spreite burrows (?Rhizocorallium) (Fig. 4d,e) (Astibia et al., in press).

\subsection{Gendulain Formation (Liédena Sandstone Member)}

The studied section culminates with the intertidal deposits of the Liédena Sandstone (Gendulain Formation) containing benthic microforaminifera of the Priabonian and abundant trace fossils of invertebrates and aquatic birds (Payros et al., 2000; Astibia et al., 2007). Identified invertebrate trace fossils in Liédena Sandstone are Cochlichnus isp., Palaeophycus tubularis and vertical tubes (Fig. 3g). The bird footprints are assigned to: Gruipeda isp., Koreanaornis isp., cf. Koreanaornis, Leptoptilostipus pyrenaicus and cf. Leptoptilostipus (Figs. 3h, 4f,g) (Astibia et al., in press).

\section{Discussion. Palaeoenvironments and comparisons}

The palaeoenvironmental information provided by the different fossil assemblages described above (foraminifers, body macrofossils and ichnofacies) is in line with the sedimentological evolution of the Pamplona Basin. Thus, both data sets record the transition from deep-sea conditions to 


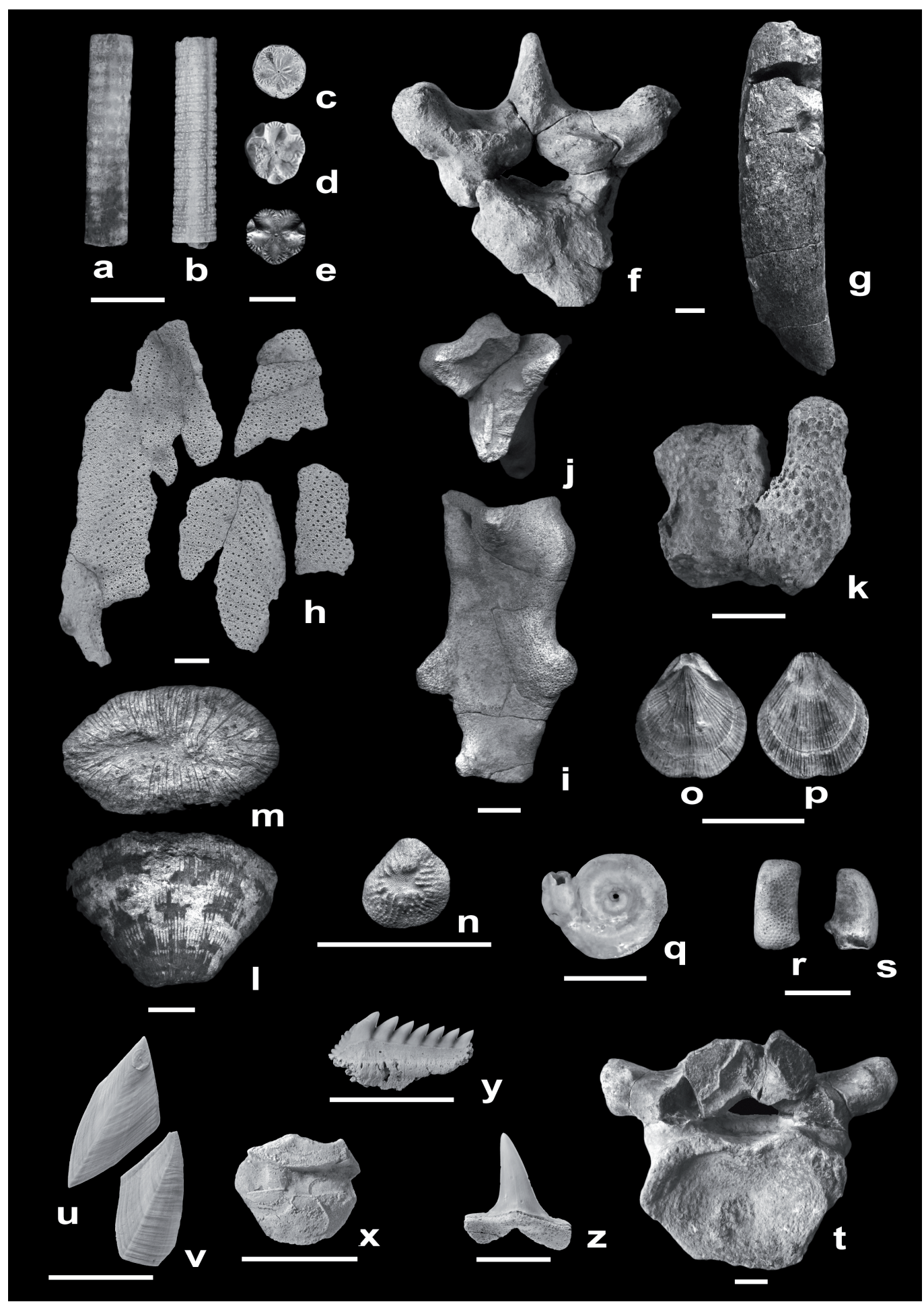

Fig. 5.- Body fossils from the middle Eocene (Bartonian) of the Pamplona Marl Formation. Isselicrinus sp.: a, UZ1.32, and b, UZ1.33, stem fragments in side view; c, UZ1.34, internodal in articular view; d, UZ1.35, and e, UZ1.36, nodals in articular view. Dugongidae indet.: f, UZ1.6, thoracic vertebra in anterior view; $\mathbf{g}$, UZ1.22, rib fragment in dorsal view. Body fossils (non-molluscs) from the middle Eocene (Bartonian) of the Ardanatz Sandstone (h-t) and Ilundain Marl (u-z) formations. Laocoetis samueli (d'Archiac, 1850): h, AD3.1.3, fragments of the same specimen, outer and inner side views. Guettardiscyphia thiolati (d'Archiac, 1846) and/or Pleuroguettardia iberica Pisera and Busquets, 2002: $\mathbf{i}-\mathbf{j}$, AD3.1.2, lower part in lateral view and cross section respectively. Stylocoenia taurinensis (Michelin, 1842): k, AD.10, fragment of a ceroid colony. Placosmiliopsis bilobatus (d'Achiardi, 1868): l-m, AD.04, lateral and upper views. Lichenoporidae indet.: n, AD3.1.14, upper view. Terebratulina tenuistriata (Leymerie, 1846): o-p, AD.50, dorsal and ventral views. Rotularia spirulaea (Lamarck, 1818): q, AD2.2.6, lower (attachment) view. Asteroidea indet.: r-s, AD.49, marginal plate, dorsal (abradial) and lateral views. Dugongidae indet.: t, AR1.6, posterior thoracic vertebra in posterior view. Arcoscalpellum sp.: u, MCNA 15164, capitular plate (tergum), external left view; v, MCNA 13736, capitular plate, (scutum), external left view. Chaetodipterus sp.: x, MCNA, right otolith. Hexanchus agassizi Cappetta, 1976: y, MCNA 10637, lingual view. Woellsteinia kozlovi Adnet, 2006: z, MCNA 10608, lingual view. Scale bars $10 \mathrm{~mm}$. 


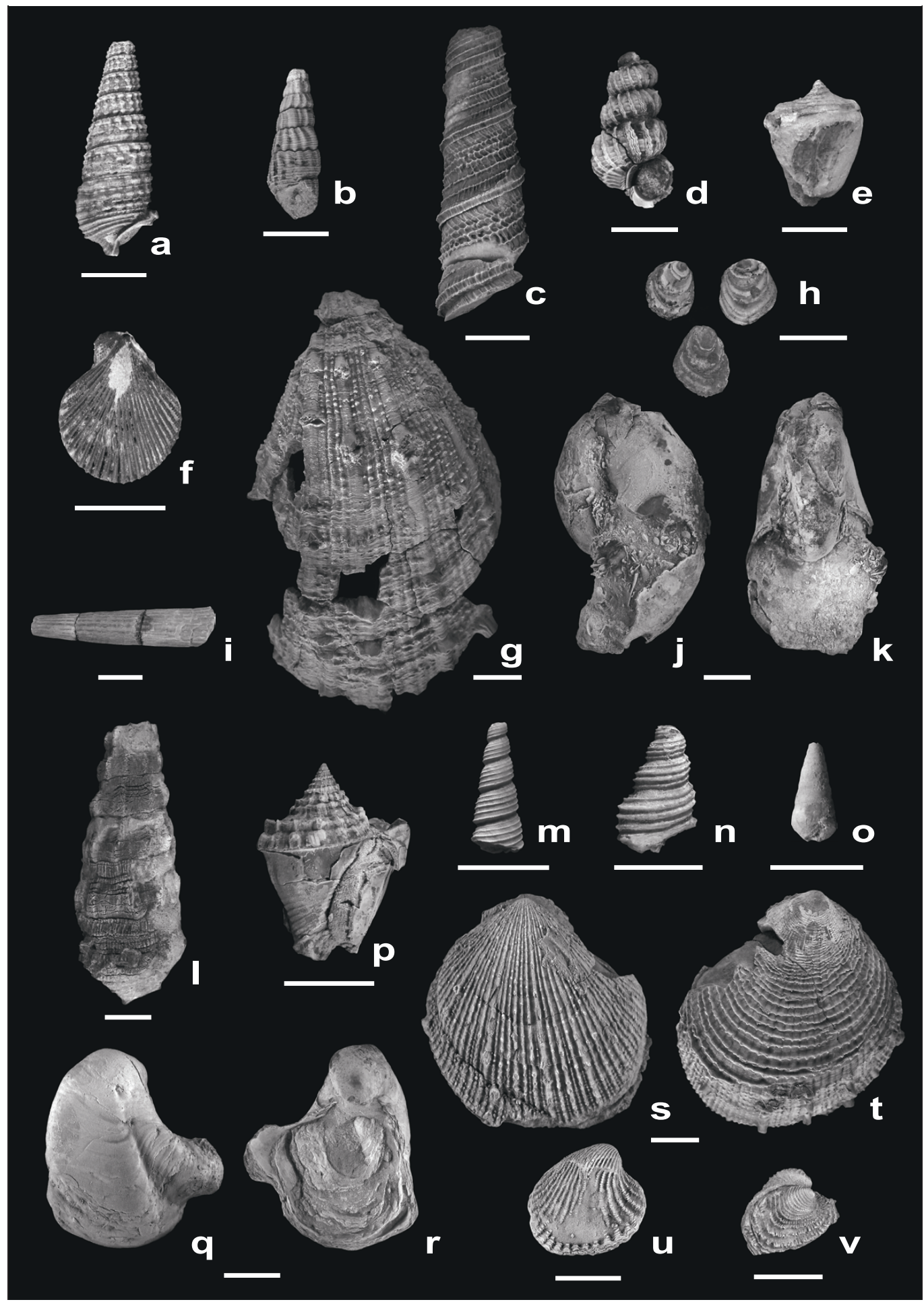

Fig. 6.- Fossil molluscs from the middle Eocene (Bartonian) of the Ardanatz Sandstone Formation. Ptychocerithium johannae (Tournouër in Bouillé, 1873): a, AG1.4.3, apertural view. Diastoma costellatum (Lamarck, 1804): b, AD1.3.3, apertural view. Haustator altavillensis (Cossmann and Pissarro, 1902): c, AD2.2.2. Cirsotrema (Elegantiscala) cf. bouillei (Tournouër in Bouillé, 1873): d, AD2.1.9, apertural view. Conidae indet.: e, AD.35, abapertural view. Chlamys sp.: f, AD6.1.1. Spondylus cf. caldesensis Carez 1881: g, AD5.1.2, right valve, external view. Dimya pamplonensis (Carez, 1881): h, TR1.1.2 (right), left valve, TR1.1.3 (left), right valve, TR1.1.4 (centre), right valve, external views. Dentalium sp.: i, AD1.3.5. Nautiloidea indet.: j-k, AD.48, lateral and septal views respectively. Fossil molluscs from middle-upper? Eocene (Bartonian- Priabonian?) of the uppermost part of the Ilundain Marl Formation. Moniquia sp.: 1, IV.1. Athleta (Volutospina) sp.: p, IV.5, apertural view. Haustator cf. imbricatarius conoideus (Sowerby J., 1814): m, IV.2. Sigmesalia sp.: n, IV.3, apertural view? Niso sp.: o, IV.4, apertural view. Pycnodonte brongniarti (Bronn, 1831): q-r, IV.9, left and right valves respectively, external views. Spondylus sp. cf. Spondylus cisalpinus Brongniart, 1823 - Spondylus nysti d'Archiac, 1846: s-t, IV.6, left and right valves, external views. Venericardia junctinova Cossmann, 1897: u, IV.7, right valve, external view. Chama pellati Boussac, 1911: v, IV.8, right valve and overlapping left valve, external views. Scale bars $10 \mathrm{~mm}$. 


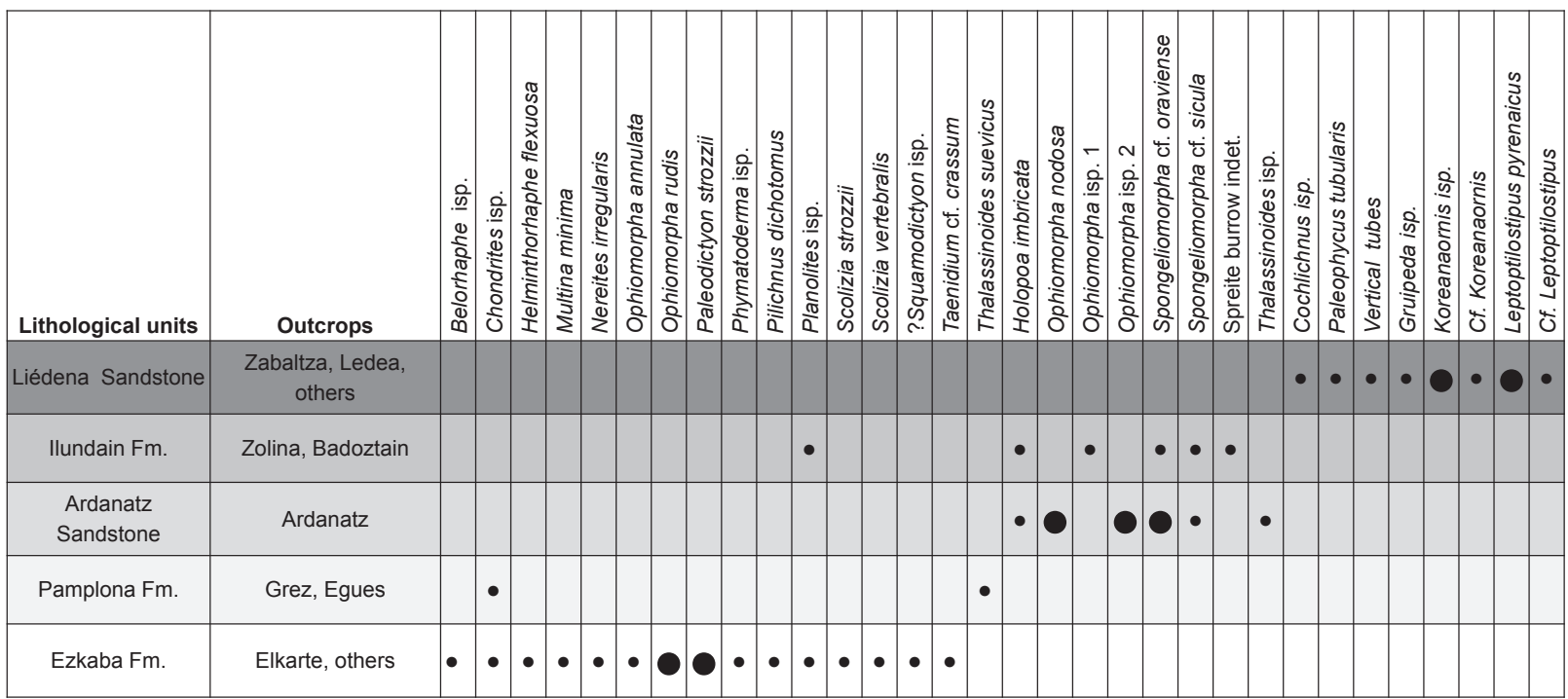

Fig. 7.- Lithostratigraphic units of the Pamplona Basin (Navarre, western Pyrenees) and vertical distribution of trace fossils. Solid dots indicate the record of different ichnotaxa in each outcrop (large dots indicate special abundance).

deltaic progradation and, eventually, a definite emersion into terrestrial conditions, which was the result of overfilling the basin as a consequence of the progressive uplift and denudation of the Pyrenees. Furthermore, the fossil assemblages allow the general paleonvironmental evolution to be analyzed more in detail and comparisons with neighbouring areas to be made.

\subsection{Ezkaba Sandstone Formation (Fig. 7)}

The trace-fossil assemblage of the Ezkaba Sandstone Formation, the older unit considered in this work, is characteristic of the deep-sea Nereites ichnofacies, as revealed by the presence of graphoglyptids (Uchman and Wetzel, 2011; Wetzel and Uchman, 2012). This agrees with the richness in planktic foraminifers of the marly deposits of this unit and the sedimentological interpretation of the Ezkaba Sandstone as channel-fill deposits of a laterally migrating channel-levee turbidite system (Payros et al., 1997).

When sandstones predominate ichnoassemblages show a low diversity and are characterized by the dominance of Ophiomorpha (O. rudis and O. annulata) and the presence of Scolicia (S. strozzii and S. vertebralis), supporting the differentiation of the Ophiomorpha rudis ichnosubfacies of the Nereites ichnofacies. The Ophiomorpha rudis ichnosubfacies, as defined by Uchman (2009), occurs in channel and proximal lobe facies of deep-sea fans or in thick-bedded fans of deep-sea clastic ramps.

In the marly stretchs with thin interbedded turbidites (Elkarte outcrop) the presence of graphoglyptids (Paleodictyon strozzii, cf. Squamodictyon isp. and Helminthorhaphe flexuosa) suggests the Paleodictyon ichnosubfacies of the Nereites ichnofacies or a mixed Paleodictyon-Ophiomorpha rudis ichnosubfacies ichnoassemblage. The Paleodictyon ichnosubfacies was defined by Seilacher (1974) for more sandy and more muddy distal flysch deposits (Uchman, 2001; Uchman and Wetzel, 2011).

These ichnosubfacies are worldwide distributed and occur in geographically and geologically nearby systems of the Ezkaba Formation, such as the Early/Middle Eocene (Ypresian-Lutetian) deep-marine systems of the Hecho Group (Ainsa-Jaca Basin, Aragon, west-central South Pyrenean Area) (Uchman, 2001; Heard and Pickering, 2008) (Fig. 2). Ophiomorpha rudis and Paleodictyon ichnosubfacies are also present in the deep-marine Eocene of the Basque Basin (Rodríguez-Tovar et al., 2010; Cummings and Hodgson, 2011).

\subsection{Pamplona Marl Formation (Figs. 7, 8)}

Upwards in the sedimentary series of the study area, in the base of the Pamplona Marl Formation, the moderately high proportion of planktic foraminifera and the high diversity and composition of benthic foraminifera, including the presence of agglutinated tubular forms (astrorhizids; Murray et al., 2011), still are indicative of relatively deep-water, outer-platform to upper slope environments (Leckie and Olson, 2003; Murray, 2006). The stalked crinoid Isselicrinus is an extinct genus (Late Cretaceous-Miocene) of wide biogeographic distribution. Fujiwara et al. (2005) described the likely way of life for the individuals, which adopted a relay strategy in the muddy substrate using pre-existing upright columns as anchorage mechanism for the attachment to the sea bottom. Isselicrinus is regarded as a crinoid adapted to low energy muddy environments (Fujiwara et al., 2005). Malubián and Olivero (2005) have indicated that the species of this genus are mostly restricted to deep-water settings in the Cenozoic. Roux et al. (2006) propose a bathymetric zonation of the genus Isselicrinus in the Eocene marls of Miretrain (Aquitaine, North-Pyrenean Basin foreland), describing four (eco)phenothypes to be indicative of depths between 200 and $1000 \mathrm{~m}$ 


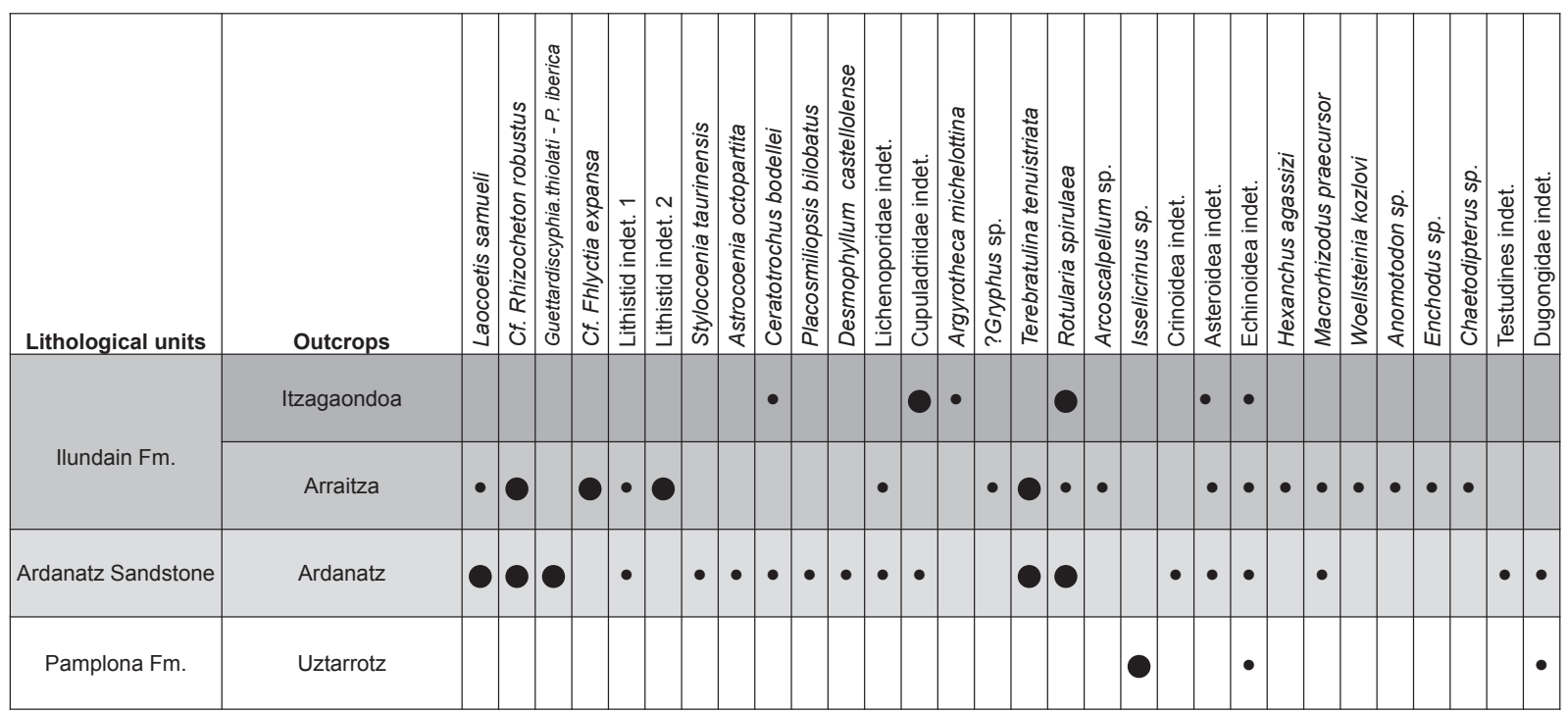

Fig. 8.- Lithostratigraphic units of the Pamplona Basin (Navarre, western Pyrenees) and vertical distribution of fossil invertebrates (nonmolluscs). Solid dots indicate the record of different taxa in each outcrop (large dots indicate special abundance).

or more. Isselicrinus (I. didactylus) is a common crinoid in the Eocene (Bartonian) of Biarritz / Miarritze (Basque Coast, southwestern Aquitaine Basin) (Roux, 1978).

Uztarrotz sirenian fossils consist of disarticulated vertebrae and ribs. They presumably come from the same individual. The sedimentological features of the Pamplona Marl Formation in Uztarrotz and their palaeontological content (microforaminifera and crinoids) indicate a deep marine environment. Therefore, it is likely that the sirenian remains correspond to an ademic organism (sensu Fernández López, 1990; 2000). Thus, the sirenian bones could have been derived from a floating carcass swept into the open sea (Astibia et al., 2005).

Fossils of Sirenia are relatively abundant in the middle and late Eocene of the northern margin of the Tethys. In the Pyrenean Realm, sirenian remains have been described in a number of middle and upper Eocene localities from the Catalonian Basin (Pilleri et al., 1989; Galobart et al., 1992). These have generally been assigned to genus Prototherium. The sirenian fossil remains found in the central-western Pyrenees were still rather scarce and fragmentary (Bouillé, 1876; Pilleri et al., 1989; Gómez, 1998; Astibia et al., 1999; 2005; 2006), but the most complete fossil collection of the oldest sea cow from Western Europe have been recently found in deltaic deposits of the Sobrarbe Formation (Ainsa Basin, Aragon) (Badiola et al., 2011; Díaz-Berenguer et al., 2014).

\subsection{Ardanatz Sandstone and Ilundain Marl formations}

(Figs. 8, 9)

As noted above, the Ardanatz Sandstone and Ilundain Marl formations are the richest units with body macrofossils in the study area. In Ardanatz outcrops (Ardanatz Sandstone Formation) the low proportion of planktic foraminifera and the high abundance of benthic foraminifera, their composition (including common porcelaneous foraminifera) and moder- ate diversity suggest a shelfal depth of deposition (Murray, 2006).

By contrast, the palaeontological and stratigraphic data indicate that the Arraitza outcrop (Ilundain Marl Formation) may correspond to somewhat deeper environments (Astibia et al., 2014). The scarcity of planktic foraminifera in Arraitza, which is slightly higher than in Ardanatz, and the diversity and composition of benthic foraminifera, including the presence of agglutinated tubular forms (Jones and Charnock, 1985; Murray et al., 2011), are indicative of outer-platform to upper-slope environments. The peak in chiloguembelinid abundance and the high abundance of benthic foraminifera may be indicative of increased local productivity in this area.

There are clear differences between the faunal compositions of the Arraitza and Ardanatz outcrops. Among the sponges Guettardiscyphia/ Pleuroguettardia have been found only in the Ardanatz AD3 section, and cf. Phlyctia expansa and indetermined lithistid sp. 2 only occur in Arraitza (Astibia et al., 2014). Corals and molluscs are less abundant and diverse in Arraitza, unlike what happens with shark teeth fossils.

Eastward in the study area and in the uppermost part of the Ilundain Marl Formation, the scarcity of planktic foraminifera and the composition of the moderately diverse benthic foraminifera (including common porcelaneous foraminifera) suggest an inner shelfal depth of deposition (Leckie and Olson, 2003; Murray, 2006).

The comparison between fossil-invertebrate associations of Ardanatz and Itzagaondoa valley outcrops highlights the existence of notable differences wetween them. In the Itzagaondoa outcrops no sponges have been found. In Ardanatz (and Arraitza) hexactinellid and lithistid sponges occur. Most hexactinellids live in rather deep waters on soft substrates (Vacelet, 1988; Tabachnik, 1991; Charbonnier et al., 2007; Pisera et al., 2006). Accordingly, the shallower sedimentary environment of the Itzagaondoa outcrops could explain their 


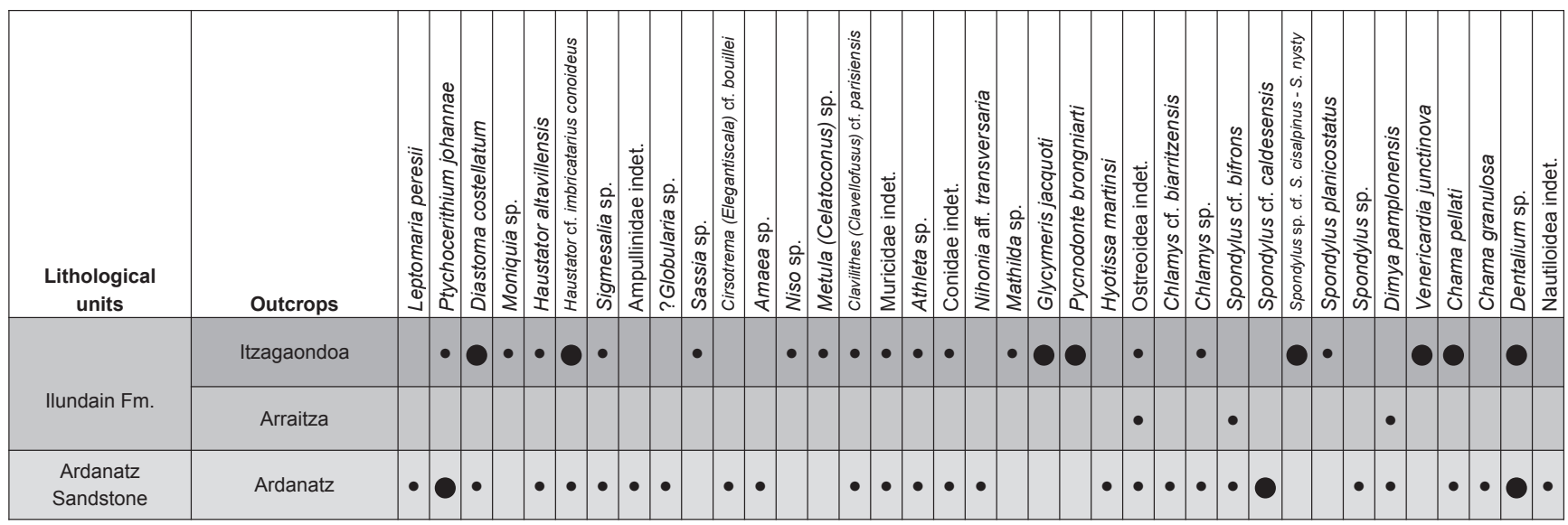

Fig. 9.- Lithostratigraphic units of the Pamplona Basin (Navarre, western Pyrenees) and vertical distribution of fossil molluscs. Solid dots indicate the record of different taxa in each outcrop (large dots indicate special abundance).

absence. Regarding the mollusc associations, the most notable differences between fossil-invertebrate associations of Ardanatz and Itzagaondoa valley outcrops are: (1) the abundance of phytophagous gastropod Ptychocerithium joahannae in Ardanatz sections and its scarcity in the Itzagaondoa valley; (2) the presence in the Ardanatz sections of Ampullinidae indet., ?Globularia sp., Cirsotrema (Elegantiscala) cf. bouillei, Amaea sp., Clavilithes (Clavellofusus) cf. parisiensis, Nihonia aff. transversaria, Spondylus cf. caldesensis, Dimya pamplonensis and Chama granulosa, among others and its absence in the Itzagaondoa localities; on the contrary (3) the abundance of phytophagous gastropod Diastoma costellatum in the Itzagaondoa outcrops and its scarcity in the Ardanatz outcrops; and (4) the presence of Moniquia sp., Sassia sp., Niso sp., Metula (Celatoconus) sp., Mathilda sp., Pycnodonte brongniarti, Spondylus planicostatus, Spondylus sp. cf. Spondylus cisalpinus-S. nysti and Venericardia junctinova in the Itzagaondoa outcrops, which are absent in the Ardanatz sections. Although differences between the composition of these associations can be observed, they share numerous phytophagous gastropods (Ptychocerithium, Diastoma, Globularia and Ampullinidae indet) reflecting shallow waters in the euphotic zone.

Trace fossil assemblages at the Ardanatz Sandstone and Ilundain Marl formations, with dominance of Thalassinoides and Ophiomorpha, could be related to the Cruziana ichnofacies. The archetypal Cruziana ichnofacies occurs from just slightly above the fair-weather base to the storm wave base, from the lower shoreface to the lower offshore, under moderate- to low-energy conditions (i.e., MacEachern et al., 1999; 2007).

Palaeoichnological data of the Ardanatz Sandstone and the lower part of the Ilundain marls fit well with the shallowing processes that throughout the middle and late Eocene occur in the area, according to the sedimentological and stratigraphic data and the other palaeontological data (body fossils) (Pujalte et al., 2002; Barnolas et al., 2004; Astibia et al., 2014; Astibia et al., in press).

\subsubsection{Comparisons with other areas}

Globally considered, the body fossil assemblages of the Ardanatz Sandstone and Ilundain Marl formations are comparable with the Eocene associations of the Basque Coast, in the southwestern Aquitaine Basin (Nord Pyrenean area), studied since the nineteenth century (d'Archiac, 1846; 1850; Bouillé, 1876; Boussac, 1911) and also with those of the Eocene (Bartonian) age of the west-central and eastern part of the South Pyrenean area, in Aragon (Jaca Basin) (Villalta, 1956; Puigdefábregas, 1975; Barnolas and Gil-Peña, 2001; Oms et al., 2003) and Catalonia (Igualada and Vic regions) (Abad, 2001; Busquets et al., 1994; Carrasco, 1994; Pisera and Busquets, 2002).

However, the studied associations of the Pamplona Basin seem to be less diverse than those from the above-mentioned areas. The lower palaeontological diversity may be due to the still preliminary nature of the studies carried out so far, which involves sampling biases (e.g. field collection of specimens which are only visible to the naked eye, the need to screenwash sediment to study the microgastropods and micromorphic brachiopods), taphonomic biases and/or palaeoecological differences (more restricted environments).

The sponge associations seem similar to those of the Eocene of Biarritz/Miarritze (Basque Coast, Aquitanian Basin) described by d'Archiac $(1846,1850)$, where Laocoetis samueli and stellate forms such as Guettardiscyphia thiolati and Pleuroguettardia iberica are the most representative sponges of the fossil assemblage.

The gastropods Ptychocerithium johannae, Diastoma costellatum, Haustator imbricatarius, and the bivalves Spondylus bifrons, Spondylus nysti, Spondylus planicostatus and Chama pellati, among other molluscs, are present in the Paleogene series of the Basque Coast, in the surroundings of the town of Biarritz, specifically in the outcrops of Villa Marbella and of the upper part of the Côte des Basques (BartonianPriabonian, Côte des Basques Marls Formation, Mathelin and Sztràkos, 1993; Sztràkos et al., 1998) (Boussac, 1908, 
1911). Spondylus nysti d'Archiac, 1846, Spondylus planicostatus d'Archiac, 1850, Chama granulosa d'Archiac, 1850 and Chama pellati Boussac, 1911 were defined in the Paleogene of Biarritz. Hyotissa martinsi was also erected by d'Archiac (1847) as "Ostrea Martinsii" in the "Nummulitique" of Biarritz. Pycnodonte brongniarti is present in the upper part (lower Oligocene?) of the Paleogene series of Anglet/Angelu and Biarritz (Chambre d'Amour and other sites) ("Ostrea vesicularis" in d'Archiac, 1846; "Ostrea Brongniarti" in Bouillé, 1876 and Boussac, 1908, 1911).

The Villa Marbella outcrop, in the lower part of the Côte des Basques blue marls, is the same site that Bouillé (1876) named "Lady Bruce" (Boussac, 1911). Tournouër (in Bouillé, 1876) described the "Cérites -Cerithiidae- des couches à Serpula spirulaea" in Lady Bruce. Bouillé (1876) cited the presence of "Serpula spirulaea" (Rotularia spirulaea) in Lady Bruce and Côte des Basques outcrops. The presence of "Serpula spirulaea" had already been reported in Biarritz by d'Archiac (1846, 1850).

Other faunal assemblages, partially comparable, are the mollusc fossil assemblages from the Eocene (Bartonian) marls of the Basa Valley (Ballibasa) (Sobás, Yebra de Basa, San Román de Basa and Isún sites, Pamplona marls sensu lato, Jaca Basin, west-central Pyrenean area, Puigdefábregas, 1975; Oms et al., 2003), situated in the neighbouring territory of Huesca (Aragon), about $120 \mathrm{~km}$ to southwest from our studied area. The fossil gastropods from these localities were studied by Villalta (1956). The faunal associations of the Pamplona and Jaca basins share close if not the same species of the genera Niso, Globularia, Clavilithes, Sassia, Moniquia (as Faunus in Villalta, 1956), some Epitoniidae and, at least, the species Haustator altavillensis and Diastoma costellatum. The Ballibasa levels are probably somewhat older that those of the Ardanatz Sandstone and Ilundain Marl Formation and their faunas (at least the molluscs) seem to be more diverse than those of Navarre. Fish otoliths of Yebra de Basa have recently been studied by Brzobohatý and Nolf (2011). The assemblage reflects a very shallow neritic environment, different of the one from the Villa Marbella in Biarritz, with a deep neritic-upper slope otolith association (Brzobohatý and Nolf, 2011).

Regarding to the Eocene of Catalonia, the Ardanatz AD3 level outcrops, with the stellate and conical siliceous sponges and erected bryozoan colonies, could be compared to the Bartonian shelf deposits from the Vic Marls Formation in the northeastern part of the Ebro Basin (Busquets et al., 1994; Pisera and Busquets, 2002; Astibia et al., 2014). Farrés (1961) cited the presence of "Cerithium Johannes" in the Bartonian marls from Gurb (Vich region). Spondylus caldesensis, Spondylus bifrons and Spondylus nysti are present in several sites of Igualada, Manresa and Vic regions, in the Igualada Formation (late Bartonian, most likely Priabonian in age, Taberner et al., 1999; Costa et al., 2013) (Carrasco, 1994; Abad, 2001). Pycnodonte brongniarti has a wide biostratigraphic and palaeobiogeographic distribution (Paleocene-Miocene, through northern Africa and southern
Eurasia) and is abundant in numerous Eocene localities of Igualada and Vic regions (Igualada Formation) (Abad, 2001).

Regarding the biogeographic relationships with the Western Europe, the mollusc associations found in the Pamplona basin share two elements found in the middle Eocene (Lutetian) of San Giovanni Ilarione (Verona basin, Italy): Clavilithes parisiensis and Diastoma costellatum (Quaggiotto and Mellini, 2008). These two faunal elements correspond to cosmopolitan species and have been also found in the Middle Eocene of the Paris Basin. Another species found in the Tethys is Leptomaria peresii occurring in the Priabonian of Alps (France). Species found in the North-West Atlantic are Haustator imbricatarius, Nihonia transversaria from the Paris Basin and Haustator altavillensis, originally described from the Middle Eocene of Normandy. As seen above, the rest of this association seems restricted of the Pyrenean area, so the existence of an endemic fauna or/and the beginning of a faunal differentiation between the Northern (Paris Basin, Normandy) and the southern faunas (Pyrenean and Aquitaine basins), which is observed since the Rupelian (Lozouet and Maestrati, 1986; Merle et al., 2002), can be proposed as a hypothesis. However, further research on this mollusc association is necessary.

\subsection{Gendulain Formation (Liédena Sandstone Member)}

(Fig. 7)

Sedimentological evidence (synaeresis cracks, flat-topped wave ripples, halite moulds, etc.) indicates a relatively confined marginal marine environment for these deposits (Payros et al., 2000).

The Liédena Sandstone ichnofauna presents a low ichnodiversity. The vertebrate tracks are exclusively composed of bird ichnotaxa and two of them, Koreanaornis and Leptoptilostipus, have been related with shorebird trackmakers (i.e., Lockley and Harris, 2010). Lockley et al. (1994) proposed the shorebird ichnofacies, which comprises ichnocoenoses of shorebirds attributable to Charadriiformes, Anseriiformes and Ciconiiformes. Gibert and Sáez (2009) considered the shorebird ichnofacies to be a subset of the Scoyenia ichnofacies (an ichnosubfacies sensu Melchor et al., 2006) that characterizes the subaerial part of low-energy shore areas. On the other hand, the presence of Cochlichnus in a non-marine setting is typical of the Mermia ichnofacies and suggests a low energy perennial freshwater environment (Hasiotis, 2002; Buatois and Mángano, 2002). The occurrence of characteristic ichnotaxa of more than one ichnofacies in a single ichnofauna, as the occurrence in Liédena deposits, could be interpreted as a consequence of the trace-fossil producers being environmentally tolerant animals that could inhabit and behave similarly in either setting. Overall, the palaeohydrological and palaeoenvironment scenario deduced from the bioturbation and other organic and sedimentary structures is consistent with extremely sensitive to water table oscillations, causing cyclic exposure and submersion of large areas, and to variations in salinity throughout the tidal cycle. 


\section{Conclusions}

Fossil associations from the middle and late Eocene (Bartonian and Priabonian) sedimentary succession of the Pamplona Basin are described. This succession accumulated in the western part of the South Pyrenean peripheral foreland basin and extends from deep-marine turbiditic (Ezkaba Sandstone Formation) to deltaic (Pamplona Marl, Ardanatz Sandstone and Ilundain Marl formations) and marginal marine deposits (Liédena Sandstone Member, Gendulain Formation).

Palaeontological data of the studied sedimentary units fit well with shallowing processes that throughout the middle and late Eocene occur in the area, in accordance with the results obtained from sedimentological and stratigraphic data.

The studied units are very rich in microfossils and ichnofossils, but not in body macrofossils, which are only locally abundant. In some outcrops of the Ardanatz Sandstone and Ilundain Marl formations fossils of sponges and erected bryozoans seem to correspond to complete or nearly complete specimens, without evidence of abrasion. They probably correspond to demic organisms. In other outcrops fossils are fragmentary and associated mainly with levels of high terrigenous content and may have undergone some taphonomic remotion processes.

Epibiontic activity and bioerosion on fossil invertebrates and sirenian ribs are frequent. The fossil invertebrates are generally fragmentary, showing dissolution, replacement by calcite and celestite, and aragonite-calcite neomorfism processes. Replacement by francolite occurs in fossil vertebrates. Microbial mats impressions have been identified in the digit impressions of some bird tracks of the Liédena Sandstone. The microbial mats may have acted as taphonomic bias favouring the preservation of vertebrate tracks and conditioning the presence of endofauna.

At least 23 ichnogenera and 28 ichnospecies have been identified in the study area. Among the body macrofossils, 78 taxa of macroforaminifers, sponges, corals, bryozoans, brachiopods, annelids, molluscs, arthropods, echinoderms and vertebrates have been reliably identified. However, both the number of ichnotaxa and invertebrate species (e. g. bryozoans and molluscs) may be considerably higher.

In the older unit, the Ezkaba Sandstone Formation, only some microfossils and ichnofossils have been determined. There, body macrofossils are scarce and fragmentary. The trace-fossil assemblage is characteristic of the deep-sea $\mathrm{Ne}$ reites ichnofacies. The Ophiomorpha rudis and the Paleodictyon ichnosubfacies can be differentiated in this unit, which are typical of channel axis and off-axis environments. They agree with the richness of planktic foraminifera of the marly deposits of this unit and the sedimentological interpretation of the Ezkaba Sandstone as channel-fill deposits of a laterally migrating channel-levee turbidite system.

The Pamplona marls are rich in microfossils but macrofossils are rare. In the base of this unit microfossils, with moderately high proportion of planktic foraminifera and high diversity and composition of benthic foraminifera, are indicative of relatively deep waters, outer-platform to upper slope environments. Stalk fragments of crinoids (Isselicrinus sp.) are quite common throughout the lower part of the Pamplona Formation. Postcranial elements of sirenian mammals (Dugongidae indet.) have also been described.

The Ardanatz Sandstone and Ilundain Marl formations are the richest sources of body macrofossils in the study area. In the Ardanatz outcrops (Ardanatz Sandstone Formation), the low proportion of planktic foraminifera and the high abundance of benthic foraminifera, their composition (including common porcelaneous foraminifera) and moderate diversity suggest a shelfal depth of deposition. Eastward, in the study area and in the uppermost part of the Ilundain Marl Formation, the scarcity of planktic foraminifera and the composition of the moderately diverse benthic foraminifera (including common porcelaneous foraminifera) suggest an inner shelfal depth of deposition.

The comparison of fossil-invertebrate associations of the locality of Ardanatz and the Itzagaondoa valley outcrops shows notable differences. In Itzagaondoa outcrops no fossil sponges have been found, and this can be explained because the Itzagaondoa outcrops represent a shallower sedimentary environment. Trace fossil assemblage at the Ardanatz Sandstone and Ilundain Marl formations could be related to the Cruziana ichnofacies.

Body fossil assemblages of Ardanatz Sandstone and Ilundain Marl formations are comparable with the Eocene (Bartonian-Priabonian) age associations of the Basque Coast (southwestern Aquitaine Basin, North Pyrenean area), specifically in the outcrops of the Côte des Basques Marls Formation. They are also comparable with those of Eocene (Bartonian-Priabonian) from the west-central and eastern part of the South Pyrenean area, in Aragon (Ballibasa, Jaca Basin) and Catalonia (Vic Marls and Igualada formations). At the Western Europe scale, the mollusc assemblages seem endemic for the Pyrenean area, although they share several cosmopolitan species with the Middle Eocene of the Tethys (Italy and France, Alps) and of the Nort-West Atlantic (Paris Basin and Normandy).

The studied associations seem to be less diverse than those from the above-mentioned areas. The lower palaeontological diversity of the Pamplona Basin may be due to the still preliminary nature of the studies carried out so far, which involves sampling and taphonomic biases and/or palaeoecological differences.

The ichnofauna of the Liédena Sandstone, in the upper part of the sedimentary succession, is composed of bird tracks, and both invertebrate horizontal and vertical structures. The assignation of this ichnofauna to a specific ichnofacies is tentative, and we regard it as showing a combination of the characteristics of the Mermia and Scoyenia ichnofacies.

In conclusion, the fossil associations found in the middleupper Eocene succession of the Pamplona Basin were found to be rich and diverse enough to allow an integrated palaeoen- 
vironmental analyses to be carried out herein for the first time. The fossil associations show similarities, but also differences, with coeval associations from neighbouring areas, such as the long-known, classic outcrops in the southwestern Aquitaine Basin, in Aragon and in Catalonia, and even in more distant areas, such as the Paris Basin. Such differences provide the Pamplona Basin a distinctive character and increase its interest for palaeobiodiversity studies. Consequently, future studies will focus on specific fossil groups.

\section{Acknowledgements}

Comments by Dr. Kai Ingemann Schnetler and an anonymous reviewer considerably improved the manuscript. Thanks to Dr. Jone Mendicoa for her technical assistance with the figures. Financial support to H.A., A.Ba., A.Be., I.D.-M., J.E. and X.P.-S. was provided by the Project CGL2013-47521-P (Ministerio de Economía y Competitividad, MINECO, Spain), the European Regional Development Fund (ERDF/ FEDER), and the research group IT-834-13 (Eusko Jaurlaritza/ Gobierno Vasco, EJ/GV). Research work of I.D.-M. was supported by a postdoctoral grant provided by the Ministerio de Ciencia, Tecnología e Innovación Productiva, CONICET, Argentina. Financial support to F.J.R.-T. was provided by the Project CGL2012-33281 (MINECO), and the research group RNM-178 (Junta de Andalucía). A.P. and S.O. were funded by project CGL 2011-23770 (MINECO) and the research group IT-215-07 (EJ/GV). This a palaeontological collaboration between the UPV/EHU, the CNRS and the MNHN (France).

\section{References}

Abad, A. (2001): Paleotaxodonta y Pteriomorphia del Eoceno del margen sur de la depresión Central Catalana. $\mathrm{PhD}$ thesis, Universitat Autònoma de Barcelona, $803 \mathrm{p}$.

Achiardi, A. d' (1868): Coralli fossili del terreno nummulitico dell'Alpi Venete. Memorie della Società Italiana di Scienze Naturali, Milano, parte 2, 4(1):1-31.

Adnet, S. (2006): Nouvelles faunes de Sélaciens (Elasmobranchii, Neoselachii) de l'Eocène moyen des Landes (Sud-Ouest, France). Implication dans la connaissance des communautés de sélaciens d'eaux profondes. Palaeo Ichthyologica 10, 1-128.

Alameda, J., Blas, I., Cabra, P., Del Valle de Lersundi, J., García, A., Martínez, A., Ramírez del Pozo, J., Solé, J. (1993): Hoja geológica num. 141-II (Pamplona). Cartografía Geológica de Navarra E. 1:25.000. Gobierno de Navarra, Departamento de Obras Públicas, Transportes y Comunicaciones, Pamplona.

Allman, G. (1856): A monograph of the fresh-water Polyzoa, including all the known species, both British and foreing. The Ray Society, London, $119 \mathrm{p}$.

Álvarez-Pérez, G. (1997): New Eocene coral species from Igualada (Barcelona, NE of Spain). Boletín de la Real Sociedad Española de Historia Natural 91, 297-304.

Archiac, A.M. d' (1846): Description des fossiles recueillis par M. Thorent dans les couches à Nummulines des environs de Bayonne. Mémoires de la Société géologique de France, 2ème série 2(4), 189-217.

Archiac, A.M., d' (1847): Extrait d'un Mémoire sur les fossiles des conches à Nummulites des environs de Bayonne et de Dax. Bulletin de la Société géologique de France, 2ème série 2(4), 1006-1010.

Archiac, A.M. d' (1850): Description des fossiles du groupe nummulitique recueillis par M.S.-P. Pratt et M.J. Delbos aux environs de Bayonne et de Dax. Mémoires de la Société géologique de France, 2ème série 3(6), 397-456.

Archiac, A. d', Haime, J. (1853): Description des animaux fossiles $d u$ groupe nummulitique de l'Inde. Gide et Baudry Eds., Paris, 164 p.

Astibia, H., Elorza, J., Pisera, A., Álvarez-Pérez, G., Payros, A., Ortiz, S. (2014): Sponges and corals from the Middle Eocene (Bartonian) marly formations of the Pamplona Basin (Navarre, western Pyrenees): taphonomy, taxonomy and paleoenvironments. Facies 60, 91-110. doi:10.1007/s10347-013-0364-2.

Astibia, H., Murelaga, X., Payros, A., Pereda, X., Tosquella, J. (1999): Tortugas y Sirenios fósiles en el Eoceno marino de Navarra y Cuenca de Jaca. Geogaceta 25, 15-18.

Astibia, H., Payros, A., Pereda Suberbiola, X., Elorza, J., Berreteaga, A., Etxebarria, N., Badiola, A., Tosquella, J. (2005): Sedimentology and taphonomy of sirenian remains from the Middle Eocene of the Pamplona Basin (Navarre, western Pyrenees). Facies 50, 463-475. doi:10.1007/s10347-004-0026-5.

Astibia, H., Pereda Suberbiola, X., Bardet, N., Payros, A., Berreteaga, A., Badiola, A. (2006): Nuevos fósiles de sirenios en el Eoceno medio de la Cuenca de Pamplona (Navarra). Revista Española de Paleontología 21, 79-91.

Astibia, H., Pereda Suberbiola, X., Payros, A., Murelaga, X., Berreteaga, A., Baceta, J.I., Badiola, A. (2007): Bird and mammal footprints from the Tertiary of Navarre (western Pyrenees). Ichnos 14, 175-184. doi:10.1080/10420940601049917.

Astibia, H., Rodríguez-Tovar, F.J., Díaz-Martínez, I., Payros, A., Ortiz, S. (in press): Trace fossils from the Middle and Upper Eocene (Bartonian-Priabonian) molasse deposits of the Pamplona Basin (Navarre, western Pyrenees): palaeoenvironmental implications. Geological Journal. doi: 10.1002/gj.2763.

Badiola, A., Pereda-Suberbiola, X., Bardet, N., Astibia, H., Berreteaga, A., Canudo, J. I., Cuenca-Bescós, G. (2011): Eocene mammalian fossil record and biodiversity from Iberia: New primate and sirenian discoveries and palaeobiogeographic implications. In: T. Lehmann, F.K. Schaal (eds.), The World at the Time of Messel: Puzzles in Palaeobiology, Palaeoenvironment, and the History of Early Primates. 22nd International Senckenberg Conference, 15th - 19th November 2011, Frankfurt am Main, Germany. Conference Volume, pp. 27-28.

Baker, P.A., Bloomer, S.H. (1988): The origin of celestite in deep-sea carbonate sediments. Geochimica et Cosmochimica Acta 52(2), 335-339.

Barnolas, A., Gil-Peña, I. (2001): Ejemplos de relleno sedimentario multiepisódico en una cuenca de antepaís fragmentada: La Cuenca Surpirenaica. Boletín Geológico y Minero 112(3), 17-38.

Barnolas, A., Payros, A., Samso, J.M., Serra-Kiel, J., Tosquella, J. (2004): La Cuenca surpirenaica desde el Ilerdiense medio al Priaboniense. In: J.A. Vera (ed.), Geología de España. Instituto Geológico y Minero de España, Sociedad Geológica de España, Madrid, pp. 313-320.

Barta-Calmus, S. (1973): Révisions de collections de madréporaires provenant du Nummulitique du sud-est de la France, de l'Italie et de la Yougoslavie septentrionales. $\mathrm{PhD}$ thesis, Université de Paris 6, $695 \mathrm{p}$.

Bieda, F. (1950): Sur quelques foraminifères nouveaux ou peu connus du Flysch des Karpates polonaises. Rocznik Polskiego Towarzystwa Geologiczniego 18, 153-168.

Borg, F. (1926): Studies on Recent cyclostomatous Bryozoa. Zoologiska bidrag från Uppsala 10, 181-507.

Bouillé, R. de (1873): Paléontologie de Biarritz et de quelques autres localités des Basses-Pyrénées. Memoires de la Première Section, Congrès Scientifique de France, 39 ${ }^{\mathrm{e}}$ Session 1, Pau, pp. 427-468.

Bouillé, R. de (1876): Paléontologie de Biarritz et de quelques autres 
localités des Basses-Pyrenées. Imprimerie et Lithographie Veronese, Pau, $71 \mathrm{p}$.

Boussac, J. (1908): Note sur la succession des faunes nummulitiques à Biarritz. Bulletin de la Société Géologique de France, 4ème série 8(5), 237-255.

Boussac, J. (1911): Études stratigraphiques et paléontologiques sur le nummulitique de Biarritz. Annales Hébert 5, 1-95.

Bromley, R.G., Ekdale, A.A., Richter, B. (1999): New Taenidium (trace fossil) in the Upper Cretaceous chalk of northwestern Europe. Bulletin of the Geological Society of Denmark 46, 47-51.

Brongniart, A.T. (1823): Observations sur les Fucoïdes. Société d'Historie Naturelle de Paris, Mémoire 1, 301-320.

Bronn, H.G. (1831): Ubersicht der Fossilen Uberreste in den tertiären subappeninischen Gebirgen. Italiens Tertiär-Gebilde und deren organische Einschlüsse. Heidelberg, xii +176 p.

Bronn, H.G. (1862) (in 1862-1866): Klassen und Ordnungen des ThierReichs, wissenschaftlich dargestellt in Wort und Bild. Dritter Band, Malacozoa. Erste Abtheilung. C. F. Winter'sche Verlagshandlung, Leipzig; Heidelberg, 1500 p. (1862: 523-650).

Bruguière, J.G. (1791): Tableau encyclopédique et méthodique de trois règnes de la nature, vol. 7. Contenant l'helminthologie, ou les vers infusoires, les vers intestins, les vers mollusques \&c., Panckoucke, Paris.

Brzobohatý, R., Nolf, D. (2011): Fish otoliths from the Middle Eocene (Bartonian) of Yebra de Basa, province of Huesca, Spain. Bulletin de l'Institut royal des Sciences naturelles de Belgique, Sciences de la Terre 81, 279-295.

Buatois, L.A., Mángano, M.G. (2002): Trace fossils from Carboniferous floodplain deposits in western Argentina: implications for ichnofacies models of continental environments. Palaeogeography, Palaeoclimatology, Palaeoecology 183(1), 71-86. doi:10.1016/ S0031-0182(01)00459-X.

Buffrénil, V. de, Astibia, H., Pereda Suberbiola, X., Berreteaga, A., Bardet, N. (2008): Variation in bone histology of middle Eocene sirenians from western Europe. Geodiversitas 30(2), 425-432.

Busquets, P., Álvarez, G., Solé de Porta, N., Urquiola, M. M. (1994): Low sedimentation rate aphotic shelves with Dendrophyllia and sponges - Bartonian of the easternmost sector of the Ebro Basin. Courier Forschungsinstitut Senckenberg 172, 265-273.

Calzada, S., Astibia, H. (1996): Sobre Plicatula pamplonensis Carez: revisión. Bulletin de la Société d'Histoire naturelle de Toulouse 132, 65-69.

Cappetta, H. (1976): Sélaciens nouveaux du London Clay de l'Essex (Yprésien du Bassin de Londres). Géobios 9(5), 551-575.

Carez, L. (1881): Étude des Terrains crétacés et tertiaires du nord de l'Espagne. F. Savy, Paris, 327 p.

Carmona, N.B., Ponce, J.J., Wetzel, A., Bournod, C.N., Cuadrado, D.G. (2012): Microbially induced sedimentary structures in Neogene tidal flats from Argentina: Paleoenvironmental, stratigraphic and taphonomic implications. Palaeogeography, Palaeoclimatology, Palaeoecology 353, 1-9. doi:10.1016/j.palaeo.2012.06.021.

Carrasco, J.F. (1994): El género Spondylus en el Eoceno del Noroeste de la Península Ibérica. Scripta Musei Geologici Seminarii Barcinonensis 226, 3-24.

Cavalier-Smith, T. (2002): The phagotrophic origin of eukaryotes and phylogenetic classification of Protozoa. International Journal of Systematic and Evolutionary Microbiology 52, 297-354.

Cendon, D.I., Ayora, C., Pueyo, J.J. (1998): The origin of barren bodies in the Subiza potash deposit, Navarra, Spain: implications for sylvite formation. Journal of Sedimentary Research 68, 43-52.

Charbonnier, S., Vannier, J., Gaillard, C., Bourseau, J.P., Hantzpergue, P. (2007): The La Voulte Lagerstätte (Callovian): Evidence for a deep water setting from sponge and crinoids communities. Palaeogeography, Palaeoclimatology, Palaeoecology 250, 216-236. doi:10.1016/j. palaeo.2007.03.013.
Cossmann, M. (1897): Estudios de algunos moluscos eocenos del Pirineo Catalán. Boletín de la Comisión del Mapa Geológico de España 23, 167-198.

Cossmann, M., O’Gorman, G. (1923): Le gisement cuisien de Gan (Basses-Pyrénées). Cossmann, Pau, 188 p.

Cossmann M., Pissarro G. (1902): Faune éocénique du Cotentin (Mollusques). 3e article. Bulletin de la Société géologique de Normandie $21,27-181$.

Costa, E., Garcés, M., López-Blanco, M., Serra-Kiel, J., Bernaola, G., Cabrera, L., Beamud, E. (2013): The Bartonian-Priabonian marine record of the eastern South Pyrenean Foreland Basin (NE Spain): A new calibration of the larger foraminifers and calcareous nannofossil biozonation. Geologica Acta 11(2), 177-193. doi:10.1344/105.000001779.

Cummings, J.P., Hodgson, D.M. (2011): Assessing controls on the distribution of ichnotaxa in submarine fan environments, the Basque Basin, Northern Spain. Sedimentary Geology 239, 162-187. doi:10.1016/j. sedgeo.2011.06.009.

Cuvier, G. (1795): Second Mémoire sur l'organisation et les rapports des animaux à sang blanc, dans lequel on traite de la structure des Mollusques et de leur division en ordre, lu à la société d'Histoire Naturelle de Paris, le 11 prairial an troisième. Magazin Encyclopédique, ou Journal des Sciences, des Lettres et des Arts 2, 433-449.

Cuvier, G. (1797): Tableau élémentaire de l'histoire naturelle des animaux. Baudouin, Paris, 710 p.

Dahl, E. (1956): On the differentiation of the topography of the Crustacean head. Acta Zoologica 37, 123-192.

Davidson, T. (1870): On Italian Tertiary Brachiopoda. Geological Magazine 7, 359-370, 399-408, 460-466.

De Renzi, M. (1971): Las faunas de moluscos fósiles del Eoceno inferior del Prepirineo de Lérida. $\mathrm{PhD}$ thesis, Universitat de Barcelona, $502 \mathrm{p}$.

De Renzi, M. (1996): La influencia de los factores tafonómicos y paleoecológicos en la distribución de los moluscos en el área tipo del Ilerdiense (Conca de Tremp, Cataluña, España). Revista Española de Paleontología, $\mathrm{N}^{\mathrm{o}}$ extraordinario, 204-214.

Díaz-Berenguer, E., Badiola, A., Canudo, J. I. (2014): First mention of sirenians (Mammalia) with functional hindlimbs in Europe (Lutetian, Southern Pyrenees, Spain). Society of Vertebrate Paleontology 75th Annual Meeting, October 14-17, Berlin, Program and Abstracts, p. 120.

Doncieux, L. (1908): Catalogue descriptif des fossiles nummulitiques de l'Aude et de l'Hérault. 2ème partie: Corbières septentrionales. Annales de l'Université de Lyon, n. sér. I, 22, 1-250.

Duméril, A.M.C. (1806): Zoologie analytique, ou méthode naturelle de classification des animaux, rendue plus facile à l'aide de tableaux synoptiques. Allais, Paris, $344 \mathrm{p}$.

Ehrenberg, C.G. (1831): Symbolae physicae. Animalia Evertebrata exclusis insectis. Series prima cum tabularum decade prima. Mittler, Berolini, $135 \mathrm{p}$.

Ehrenberg, C.G. (1834): Beiträge zur physiologischen Kenntniss der Corallenthiere im allgemeinen, und besonders des rothen Meeres, nebst einem Versuche zur physiologischen Systematik derselben. $A b$ handlungen der Königlichen Akademie der Wissenschaften, Berlin. $1,225-380$.

Farrés, F. (1961): Enumeración de las especies halladas en el Eoceno de la Comarca de Vich. Revista Ausa 4(36), 44-69.

Fernández López, S. (1990): El significado de la autoctonía / aloctonía tafonómica. In: S. Fernández López (coord.), Comunicaciones de la Reunión Tafonomía y Fosilización. Universidad Complutense de Madrid, pp.115-124.

Fernández López, S. (1991): Taphonomic concepts for a theoretical biochronology. Revista Española de Paleontología 6(1), 37-49.

Fernández López, S.R. (2000): Temas de Tafonomía. Departamento de Paleontología, Universidad Complutense de Madrid, 167 p.

Frey, H., Leuckart, R. (1847): Beiträge zur Kenntniss wirbelloser Thiere mit besonderer Berücksichtigung der Fauna des Norddeutschen 
Meeres. Braunschweig, 170 p. +2 pls.

Fujiwara, S.-I., Oji, T., Tanaka, Y., Kondo, Y. (2005): Relay strategy and adaptation to a muddy environment in Isselicrinus (Isselicrinidae: Crinoidea). Palaios 20, 241-248. doi:10.2110/palo.2004.p04-25.

Galobart, A., Maroto, J., Ros, J. (1992): Troballa d'un sireni de l'eocè a la vall del Llémena. Quaderns del Centre d'Estudis Comarcals de Banyoles 1990-91, 85-94.

Gibert, J.M. de, Sáez, A. (2009): Paleohydrological significance of trace fossil distribution in Oligocene fluvial-fan-to-lacustrine systems of the Ebro Basin, Spain. Palaeogeography, Palaeoclimatology, Palaeoecology 272(3-4), 162-175. doi:10.1016/j.palaeo.2008.10.030.

Goldfuss, A. (1840): Petrefacta Germaniae, 2. Arz \& Co., Dusseldorf, $312 \mathrm{p}$.

Gómez, G. (1998): Dos sirenios del Eoceno en la formación BelsuéAtarés. Serrablo 28(110), 1 p.

Grant, R. E. (1836): Animal Kingdom. In: R.B. Todd (ed.), The Cyclopedia of Anatomy and Physiology 1, Sherwood, Gilbert and Piper, London, pp. 107-118.

Grube, A. E. (1850): Die Familien der Anneliden. Archiv für Naturgeschichte 16(1), 249-364.

Haeckel, E. (1874): Anthropogenie, oder Entwickelungsgeschichte des Menschen. Verlag von Wilhelm Engelmann, Leipzig, 732 p.

Hall, J. (1847): Paleontology of New York, vol. 1. Containing descriptions of organic remains of the Lower Division of the New York System (equivalent to the Lower Silurian rocks of Europe). C. van Benthuysen, Albany, State of New York, 338 p.

Hasiotis, S.T. (2002): Continental Trace Fossils. SEPM (Society for Sedimentary Geology) Short Course Notes 51, Tulsa, Oklahoma, 132 p.

Heard, T.G., Pickering, K.T. (2008): Trace fossils as diagnostic indicators of deep-marine environments, Middle Eocene Ainsa-Jaca basin, Spanish Pyrenees. Sedimentology 55, 809-844. doi:10.1111/j.13653091.2007.00922.x.

Huxley, T.H. (1880): On the application of the laws of evolution to the arrangement of the Vertebrata and more particularly of the Mammalia. Proceedings of the Zoological Society of London 1880, 649-662.

Huyghe, D., Merle, D., Lartaud, F., Cheype, E., Emmanuel L. (2012): Middle Lutetian climate in the Paris Basin: implications for the hotspot of biodiversity. Facies 58, 587-604. doi:10.1007/s10347-0120307-3.

Jones, R.W., Charnock, M.A. (1985): “Morphogroups" of agglutinating foraminifera. Their life positions and feeding habits and potential applicability in (paleo)ecological studies. Revue de Paléobiologie 4(2), 311-320.

Kacharava, Z.D. (1969): On the phylogenetic sequence of the Nummulites fabianii Grup. Bulletin of the Academy of Sciences of the Georgian SSR, 55 (2), 497-500.

Klein, J.T. (1734): Naturalis disposition echinodermatium. Accesseit Lucubratiuncula des aculeis echinorum marinorum, cun Spicilegio de belemnitis. Liutteris Schreiberianis, Gedani, $78 \mathrm{p}$.

Klein, E. E. (1885): Beiträge zur Bildung des Schädels der Knochenfische. II. Jahreshefte des Vereins für vaterländische Naturkunde in Württemberg 41, 107-261.

Książkiewicz, M. (1977): Trace fossils in the Flysch of the Polish Carpathians. Palaeontologia Polonica 36, 1-208.

Lamarck, J.-B. de (1804a): Mémoires sur les fossiles des environs de Paris, comprenant la détermination des espèces qui appartiennent aux animaux marins sans vertèbres, et dont la plupart sans figures dans la collection des vélins du muséum. Annales du Muséum National d'Histoire Naturelle 4, 46-55, 105-115, 212-222, 289-298, 429-436.

Lamarck, J.-B. de (1804b): Mémoires sur les fossiles des environs de Paris. Annales du Muséum National d'Histoire Naturelle 5, 28-36.

Lamarck, J.-B. de (1809): Philosophie zoologique; ou, Exposition des considérations relatives à l'histoire naturelle des animaux; à la diversité de leur organisation et des facultés qu'ils in obtiennent; aux causes physiques qui maintiennent en eux la vie et donnent lieu aux mouvemens qu'ils exécutent; enfin, à celles qui produisent, les unes le sentiment, et les autres l'intelligence de ceux qui en sont doués. Dentu, Paris, 1, 428 p., 2, 475 p.

Lamarck, J.-B. de (1818): Histoire naturelle des animaux sans vertèbres, présentant les caractères généraux et particuliers de ces animaux, leur distribution, leurs classes, leurs familles, leurs genres et la citation des principales espèces qui s'y rapportent, précédée d'une introduction offrant la détermination des caractères essentiels de l'animal, sa distinction du végétal et des autres corps naturels, enfin, l'exposition des principes fondamentaux de la zoologie, 5. Deterville et Verdière, Paris, $612 \mathrm{p}$.

Latreille, P.A. (1802): Histoire naturelle, générale et particulière des crustacés et des insectes. F. Dufart, Paris.

Laurenti, J.N. (1768): Specimen medicum, exhibens synopsin reptilium emendatam cum experimentis circa venena et antidota reptilium austracorum. Vienna, Joan. Thomae nob. de Trattnern, 214 p.

Lebrun, P., Courville, P., Pacaud J.-M. (2013): Les mollusques des sables éocènes du Bois-Gouët (Loire Atlantique). Fossiles, Revue française de Paléontologie, vol. hors-série 3 (2012), 57-7.

Leckie, R.M., Olson, H. (2003): Foraminifera as proxies of sea-level change on siliciclastic margins. In: H.C. Olson, R.M. Leckie (eds.), Micropaleontologic Proxies of Sea-Level Change and Stratigraphic Discontinuities. Tulsa, SEPM (Society of Sedimentary Geology), Special Publication 75, 5-19.

Leon Chirinos, I. (1985): Étude sédimentologique et reconstitution du cadre géodynamique de la sédimentation détritique fini-éocène-oligocène dans le bassin sud-pyrénéen entre Sanguesa et Pamplona. $\mathrm{PhD}$ thesis, University of Pau, France, 247 p.

Leriche, M. (1905): Les poissons tertiaires de la Belgique. II. Les poissons éocènes. Mémoires du Musée Royal d'Histoire Naturelle de Belgique 11(3), 49-228.

Leske, N.G. (1778): Jacobi Theodori Klein naturalis dispositio echinodermatum. Accesserunt Lucubratiuncula de aculeis echinorum marinorum et Spicilegium de belemnitis. Edita et descriptionibus novisque inventis et synonomis auctorem aucta. Addimenta ad I. T. Klein naturalem dispositionem Echinodermatum. G. E. Beer, Leipzig, xxii + $278 \mathrm{p}$.

Leymerie, M.A. (1846): Mémoire sur le terrain à Nummulites (Epicrétacé) des Corbières et de la Montagne Noire. Mémoires de la Société Géologique de France, 2ème série 1(8), 337-373.

Linnaeus, C. (1758): Systema Naturae per Regna Tria Naturae, Secundum Classes, Ordines, Genera, Species, cum Characteribus, Differentiis, Synonymis, Locis. Tenth edition. Laurentii Salvii, Holmiae (Stockholm), $824 \mathrm{p}$.

Lockley, M., Hunt, A., Meyer, C. (1994): Vertebrate tracks and the ichnofacies concept: implications for palaeoecology and palichnostratigraphy. In: S. K. Donovan (ed.), The Paleobiology of Trace Fossils. John Wiley and Sons, Chichester, pp. 241-268.

Lockley, M.G., Harris, J. (2010): On the trail of early birds: a review of the fossil footprint records of avian morphological and behavioral evolution. In: P.K. Ulrich, J. H. Willett (eds.), Trends in ornithology research. Nova Publishers, Hauppauge, NY, pp. 1-63.

Lozouet, P., Maestrati, P. (1986): Le Strombus granulatus Swainson, 1822 : une relique mésogéenne. Xenophora, 31, 11-15.

Lundgren, B. (1891): Studier öfver fossilförande lösa block. Geologiska Föreningens i Stockholm Förhandlingar 13(2), 111-121.

MacEachern, J.A., Zaitlin, B.A., Pemberton, S.G. (1999): A sharp-based sandstone of the Vinking Formation, Joffre Field, Alberta, Canada: criteria for recognition of transgressively incised shoreface complexes. Journal of Sedimentary Research 69, 876-892.

MacEachern, J.A., Bann, K.L., Pemberton, S.G. and Gingras, M.K. (2007): The Ichnofacies paradigm: High-resolution paleoenvironmental interpretation of the rock record. In: J.A. MacEachern, K.L. Bann, M.K. Gingras, S.G. Pemberton (eds.), Applied Ichnology. Society for Sedimentary Geology Short Course Notes, pp. 27-64. 
Malubián, N., Olivero, E.B. (2005): Shallow-water lat middle Eocene crinoids from Tierra del Fuego: a new southern record of a retrograde community structure. Scientia Marina 69 (Suppl. 2), 349-353.

Mangìn, J.Ph. (1959-60): Le nummulitique sud-pyrénéen a l'ouest de l'Aragon. Pirineos 51-58, 1-656.

Marty, D., Strasser, A., Meyer, C.A. (2009): Formation and taphonomy of human footprints in microbial mats of present-day tidal-flat environments: implications for the study of fossil footprints. Ichnos 16, 127-142. doi:10.1080/10420940802471027.

Mathelin, J.C., Sztràkos, K. (1993): L’Eocène de Biarritz (Pyrénées-Atlantiques, SW France). Stratigraphie et paléoenvironnement. Monographie des foraminifères. Cahiers de Micropaléontologie (nouvelle série) 8(1-2), 5-85.

Mayer-Eymar, K. (1876): Systematisches Verzeichniss der Versteinerungen des Parisian der Umgegend von Einsiedeln. Caesar Schmidt, 100 p., 4 pls.

Melchor, R.N., Bedatou, E., Valais, S. de, Genise, J.F. (2006). Lithofacies distribution of invertebrate and vertebrate trace-fossil assemblages in an Early Mesozoic ephemeral fluvio-lacustrine system from Argentina: implications for the Scoyenia ichnofacies: Palaeogeography, Palaeoclimatology, Palaeoecology 239, 253-285. doi:10.1016/j. palaeo.2006.01.011.

Merle, D. (2008): Le Lutétien : un exemple de point-chaud de la paléobiodiversité. In: D. Merle (ed.), Stratotype Lutétien. Collection Patrimoine géologique. Biotope, Mèze; Muséum national d'Histoire naturelle, Paris; BRGM, Orléans, pp. 174-181.

Merle, D., de Franceschi, D., Masure, E., Chaix, C., Roman, J., Dutheil, D., Lapierre, H., Gaudant, J., de Lapparent, F., Jouve, S., Rage, J.C., Gheerbrant, E., Carriol, R.-P., Guernet, C., Pacaud, J.-M., Moissette, P. (2008): Le contenu paléontologique du Lutétien. In: D. Merle (ed.), Stratotype Lutétien. Collection Patrimoine géologique. Biotope, Mèze; Muséum national d'Histoire naturelle, Paris; BRGM, Orléans, Cdrom, $105 \mathrm{p}$.

Merle, D., (2009): Les grandes lignes de la biodiversité. Le milieu marin. Géochronique 109 (dossier Lutétien), 20-22.

Merle, D., Baut J.-P., Ginsburg, L., Sagne, S., Hervet, S., Carriol, R.P., Vénec-Peyré, M-T., Blanc-Valleron, M.-T., Mourer-Chauviré, C., Arambol, D., Viette, P. (2002): Découverte d'une faune de vertébrés dans l'Oligocène inférieur de Vayres-sur-Essonne (bassin de Paris, France) : biodiversité et paléoenvironnement. Comptes Rendus Palevol 1, 111-116. doi:10.1016/S1631-0683(02)00018-0.

Michelin, J. L. H. (1842): Iconographie zoophytologique. Description par localités et terrains des polypiers fossiles de France, et pays environnants. P. Bertrand Eds., Paris, 348 p.

Miller, J.S. (1821): A natural history of the Crinoidea or lily-shaped animals, with observations on the genera Asteria, Euryale, Comatula, and Marsupites. C. Frost, Bristol, $150 \mathrm{p}$.

Montfort, D.P. de (1808): Conchyliologie systématique et classification méthodique des coquilles. F. Schoell, Paris, 410 p.

Murray, J.W. (2006): Ecology and applications of benthic foraminifera. Cambridge University Press, Cambridge, $426 \mathrm{p}$.

Murray, J. W., Alve, E., Jones, B. W. (2011): A new look at modern agglutinated benthic foraminiferal morphogroups: their value in palaeoecological interpretation. Palaeogeography, Palaeoclimatology, Palaeoecology 309, 229-241. doi:10.1016/j.palaeo.2011.06.006.

Mutti, E., Tinterri, R., Benevelli, G., Di Biase, D., Cavanna, G. (2003): Deltaic, mixed and turbidite sedimentation of ancient foreland basin. Marine and Petroleum Geology 20, 733-755. doi:10.1016/j.marpetgeo.2003.09.001.

Mutti, E., Tinterri, R., Di Biase, D., Fava, L., Mavilla, N., Angella, S., Calabrese, L. (2000): Delta-front facies associations of ancient flooddominated fluvio-deltaic systems. Revista de la Sociedad Geológica de España 13, 165-190.

Oms, O., Dinarès-Turell, J., Remacha, E. (2003): Magnetic stratigraphy from deep clastic turbidites: an example from the Eocene Hecho
Group (Southern Pyrenees). Studia Geophysica et Geodaetica 47, 275-288.

Oppenheim P. (1901): Über einige alttertiäre Faunen der Österreichisch-Ungarischen Monarchie. Beiträge zur Paläontologie und Geologie Österreich-Ungarns und des Orients 13, 145-277.

Orbigny, A. d' (1826): Tableau méthodique de la classe des Céphalopodes. Annales des Sciences Naturelles 7, 245-314.

Orbigny, A. d' (1850): Prodrome de Paléontologie stratigraphique universelle des animaux mollusques et rayonnés, vol. 2. Masson, Paris, $427 \mathrm{p}$.

Payros, A., Astibia, H., Cearreta, A., Pereda-Suberbiola, X., Murelaga, X., Badiola, A. (2000): The Upper Eocene South Pyrenean Coastal Deposits (Liédena Sandstone, Navarre): Sedimentary Facies, Benthic Foraminifera and Avian Ichnology. Facies 42, 107-132. doi: 10.1007/ BF02562569.

Payros, A., Pujalte, V., Orue-Etxebarria, X., Baceta, J.I. (1997): Un sistema turbidítico Bartoniense de tipo "channel-levee" en la Cuenca de Pamplona: implicaciones tectónicas y paleogeográficas. Geogaceta 22, 145-148.

Payros, A., Pujalte, V., Tosquella, J., Orue-Etxebarria, X. (2010): The Eocene storm-dominated foralgal ramp of the western Pyrenees (Urbasa-Andia Formation): an analogue of future shallow-marine carbonate systems? Sedimentary Geology 228, 184-204. doi:10.1016/j. sedgeo.2010.04.010.

Pilleri, G., Biosca, J., Via, L. (1989): The Tertiary Sirenia of Catalonia. Brain Anatomy Institute, University of Berne, Ostermundigen, Berne, 98 p.

Pisera, A., Busquets, P. (2002): Eocene siliceous sponges from the Ebro Basin (Catalonia, Spain). Les éponges siliceuses de l'Éocène du Basin de l'Èbre (Catalogne, Espagne). Geobios 35, 321-346. doi:10.1016/ S0016-6995(02)00030-X.

Pisera, A., Cachão, M., Marques de Silva, C. (2006): Siliceous sponge spicules from the Miocene Mem Moniz marls (Portugal) and their environmental significance. Rivista Italiana di Paleontologia e Stratigrafia 112 (2), 287-299. doi: http://dx.doi.org/10.13130/20394942/6342.

Plaziat, J. C. (1981): Late Cretaceous to Late Eocene paleogeographic evolution of southwest Europe. Palaeogeography, Palaeoclimatolology, Palaeoecology 36, 263-320. doi:10.1016/0031-0182(81)90110-3.

Pomel, A. (1872): Paléontologie, ou Description des animaux fossiles de la province d'Oran, avec planches lithographiées. $5^{e}$ fascicule. Spongiaires. A.D. Perrier, Oran, $256 \mathrm{p}$.

Puigdefábregas, C. (1975): La sedimentación molásica en la cuenca de Jaca. Pirineos 104, 1-188.

Pujalte, V., Baceta, J.I., Payros, A. (2002): Tertiary: Western Pyrenees and Basque-Cantabrian region. In: W. Gibbons, T. Moreno (eds.), The Geology of Spain. Geological Society of London, London, pp. 293-301.

Quaggiotto, E., Mellini, A. (2008): Catalogo Aggiornato Dei Molluschi Fossili Eocenici Di San Giovanni Ilarione (Verona - Italia Settentrionale) Prima Parte: Mollusca, Gastropoda. Studi e Ricerche 15, 41-58.

Raaf, J. F. M. de, Beets, C., Kortenbout van der Sluijs, G. (1965): Lower Oligocene bird-tracks from northern Spain. Nature 207, 146-148.

Renema, W., Bellwood, D.R., Braga, J.C., Bromfield, K., Hall R., Johnson, K.G., Lunt, P., Meyer, C. P., McMonagle, L., Morley, R. J., O'dea, A., Todd, J. A., Wesselingh, F. P., Wilson, M. E. J., Pandolfi, J. M. (2008): Hopping hotspots: Global shifts in marine biodiversity. Science 321, 654-658. doi:10.1126/science.1155674.

Rieth, A. (1932): Neue Funde spongeliomorpher Fucoiden aus dem Jura Schwabens. Geologische und Paläontologische Abhandlungen N.F. 19, 257-294.

Rodríguez-Tovar, F.J., Uchman, A., Payros, A., Orue-Etxebarria, X., Apellaniz, E., Molina, E. (2010): Sea-level dynamics and palaeoecological factors affecting trace fossil distribution in Eocene turbiditic deposits (Gorrondatxe section, N Spain). Palaeogeography, 
Palaeoclimatology, Palaeoecology 285, 50-65. doi:10.1016/j.palaeo.2009.10.022

Rouault, A. (1850): Description des fossiles du terrain éocène des environs de Pau. Mémoires de la Société géologique de France, 2 ème série, 3 (2), 457-502.

Roux, M. (1978): Les Crinoïdes pédonculés (Échinodermes) du genre Conocrinus provenant de l'Éocène des environs de Biarritz. Comptes Rendus de l'Académie des sciences, série D 286, 265-268.

Roux, M., Cahuzac, B., Sztràkos, K. (2006): Les paléoenvironnements éocènes à crinoïdes pédonculés des marnes de Miretrain (Angoumé, SW France): interprétations paléobathymétriques. Comptes Rendus Géoscience 338(4), 262-271. doi:10.1016/j.crte.2006.01.001.

Ruiz de Gaona, M. (1947): El Bartoniense de la Cuenca de Pamplona. Notas y Comunicaciones del Instituto Geológico y Minero de España 17, 155-165.

Ruiz de Gaona, M., Colom, G. (1950): Estudios sobre las sinecias de los foraminíferos eocénicos de la vertiente meridional del Pirineo (Cataluña-Vizcaya). Estudios Geológicos 12, 293-434.

Savi, P., Meneghini, G.G. (1850): Osservazioni stratigrafiche e paleontologische concernati la geologia della Toscana e dei paesi limitrofi. Appendix. In: R. I. Murchison (ed.), Memoria sulla struttura geologica delle Alpi, degli Apennini e dei Carpazi. Stamperia granducale, Firenze, pp. 246-528.

Schaub, H. (1962): Über einige stratigraphische wichtige NummulitenArten. Eclogae Geologicae Helvetiae 55(2), 529-551.

Schaub, H. (1981): Nummulites et Assilines de la Téthys paléogène. Taxinomie, Phylogenèse et Biostratigraphie. Memoires Suisses de Paléontologie 104, 1-236.

Schafhäutl, K. E. von (1851): Geognostische Untersuchungen des südbayerischen Alpengebirges. Literarisch-artistische Anstalt, Munich, $206 \mathrm{p}$.

Schieber, J. (1999): Microbial mats in terrigenous clastics: the challenge of identification in the rock record. Palaios 14, 3-12. doi: $10.2307 / 3515357$.

Schieber, J. (2002): Sedimentary pyrite: A window into the microbial past. Geology 30(6), 531-534. doi:10.1130/0091-7613(2002)030<0531:SP AWIT>2.0.CO;2.

Schmidt, O. (1870): Grundzüge einer Spongien-Fauna des atlantischen Gebietes. Wilhelm Engelmann, Leipzig, iii-iv +88 p.

Seilacher, A. (1974): Flysch trace fossils: evolution of behavioural diversity in the deep sea. Neues Jahrbuch für Geologie und Paläontologie Monatshefte 1974, 223-245.

Seilacher, A. (2007): Trace Fossil Analysis. Springer, Berlin, Heidelberg, $226 \mathrm{p}$.

Serra-Kiel, J., Hottinger, L., Caus, E., Drobne, K., Ferrández, C., Jauhri, A.K., Less, G., Pavlovec, R., Pignatti, J., Samsó, J. M., Schaub, H., Sirel, E., Strougo, A., Tambareau, Y., Tosquella, J., Zakrevskaya, E. (1998): Larger foraminiferal biostratigraphy of the Tethyan Paleocene and Eocene. Bulletin de la Société géologique de France 169, 281-299.

Siebold, K.T. von (1848). Lehrbuch der vergleichenden Anatomie der Wirbellosen Thiere. In: C.T. von Siebold, F.H. Stannius (eds.), Lehrbuch der vergleichenden Anatomie. Verlag von Veit and Comp., Berlin.
Silvestri, A. (1928): Di alcune facies Litho-Paleontologiche del Terziario di Derna, nella Cirenaica. Bolletino della Società Geologica Italiana 37, 109-113.

Sollas, W. J. (1875): Sponges. In: Encyclopedia Britannica, 9th ed., London, $451 \mathrm{p}$.

Sowerby, G. B. Jr. (1841): Conchological illustrations. Sowerby, London.

Sztràkos K., Gély J. P., Blondeau A., Müller, C. (1998): L'Éocène du Bassin sud-aquitain : lithostratigraphie, biostratigraphie et analyse séquentielle. Géologie de la France 4, 57-105.

Tabachnik, K. R. (1991): Adaptation of the hexactinellid sponges to deep-sea life. In: J. Reitner, H. Keupp (eds.), Fossil and Recent sponges. Springer Verlag, Berlin, pp. 378-386.

Taberner, C., Marshall, J. D., Hendry, J. P. Pierre C., Thirlwall, M. F. (2002): Celestite formation, bacterial sulphate reduction and carbonate cementation of Eocene reefs and basinal sediments (Igualada, NE Spain). Sedimentology 49, 171-190. doi:10.1046/j.13653091.2002.00437.x.

Taberner, C., Dinarès-Turell, J., Giménez, J., Docherty, C. (1999): Basin infill architecture and evolution from magnetostratigraphic cross-basin correlations in the southeastern Pyrenean foreland basin. Geological Society of America Bulletin 111(8), 1155-1174. doi:10.1130/00167606(1999) $111<1155$ :BIAAEF $>2.3 . \mathrm{CO} ; 2$.

Torell, O. M. (1870): Petrifacta Suecana Formationis Cambricae. Lunds Universitet, Arsskrift. Lund 6: 1-14.

Uchman, A. (1995): Taxonomy and palaeoecology of flysch trace fossils: The Marnoso-arenacea Formation and associated facies (Miocene, Northern Apennines, Italy). Beringeria 15, 3-115.

Uchman, A. (1999): Ichnology of the Rhenodanubian Flysch (Lower Cretaceous-Eocene) in Austria and Germany. Beringeria 25, 65-171.

Uchman, A. (2001): Eocene flysch trace fossils from the Hecho Group of the Pyrenees, northern Spain. Beringeria 28, 3-41.

Uchman, A. (2009): The Ophiomorpha rudis ichnosubfacies of the Nereites ichnofacies: characteristics and constraints. Palaeogeography, Palaeoclimatology, Palaeoecology 276, 107-119. doi:10.1016/j.palaeo.2009.03.003.

Uchman, A., Wetzel, A. (2011): Deep-sea ichnology: the relationships between depositional environment and endobenthic organisms. In: H. Hüneke, T. Mulder (eds.), Deep-sea Sediments. Developments in Sedimentology 63, Elsevier, Amsterdam, pp. 517-556.

Vacelet, J. (1988): Indications de profondeur données par les Spongiaires dans les milieux benthiques actuels. Géologie Méditerranéenne $15,13-26$.

Villalta, F. de (1956): Los moluscos fósiles del Eoceno pirenaico. Boletín del Instituto Geológico y Minero de España 67, 119-235.

Wetzel, A., Uchman, A. (2012): Hemipelagic and pelagic basin plains. In: D. Knaust, R.G. Bromley (eds.), Trace Fossils as Indicators of Sedimentary Environments. Developments in Sedimentology 64, Elsevier, Amsterdam, pp. 673-702.

Williams, A., Carlson, S. J., Brunton, C. H. C., Holmer, L. E., Popov, L. (1996): A supra-ordinal classification of the Brachiopoda. Philosophical Transactions of the Royal Society B 351, 1171-1193.

\section{Appendix I}

Ichnotaxa and macrofossil taxa recorded so far in the Eocene of the Pamplona Basin and surrounding areas (Navarre, western Pyrenees)

\section{Ezkaba Sandstone Formation}

\section{Ichnotaxa}

Belorhaphe isp.

Chondrites isp.

Helminthoraphe flexuosa Uchman, 1995

Multina minima (Uchman, 2001)

Nereites irregularis (Schafhäutl, 1851)
Ophiomorpha annulata (Książkiewicz, 1977) Ophiomorpha rudis (Książkiewicz, 1977)

Paleodictyon strozzii Meneghini in Savi and

Meneghini, 1850

Phymatoderma isp.

Pilichnus dichotomus Uchman, 1999
Planolites isp.

Scolizia strozzii (Savi and Meneghini, 1850)

Scolizia vertebralis Książkiewicz, 1977

?Squamodictyon isp.

Taenidium crassum Bromley, Ekdale and Richter, 1999 


\section{Ichnotaxa}

Chondrites isp.

Ophiomorpha isp.

Thalassinoides suevicus (Rieth, 1932)

\section{Ichnotaxa}

Halopoa imbricate Torell, 1870

Ophiomorpha isp.

Ophiomorpha isp. (aff. O. nodosa-O. irregulaire)

Ophiomorpha nodosa Lundgren, 1891

Planolites isp.

Spongeliomorpha cf. oraviense

Spongeliomorpha cf. sicula

Spreite burrows (?Rhizocorallium)

Thalassinoides isp.

Taxa

Rhizaria Cavalier-Smith, 2002

Foraminifera d'Orbigny, 1826

Assilina schwageri (Silvestri, 1928)

Heterostegina reticulata $\mathrm{cf}$. multifida (Bieda, 1950)

Nummulites cf. beaumonti d'Archiac and Haime, 1853

Nummulites aff. biedai Schaub, 1962

Nummulites aff. cyrenaicus Schaub, 1981

Nummulites cf. perforatus (de Montfort, 1808)

Nummulites ptukhiani Kacharava, 1969

Nummulites praegarnieri Schaub, 1981

\section{Porifera Grant, 1836}

Hexactinellida Schmidt, 1870

Laocoetis samueli (d'Archiac, 1850)

cf. Rhizocheton robustus Pisera and Busquets, 2002

Guettardiscyphia thiolati (d'Archiac, 1846) and/or

Pleuroguettardia iberica Pisera and Busquets, 2002

Demospongia Sollas, 1875

Cf. Phlyctia expansa Pomel, 1872

Lithistid indet. 1

Lithistid indet. 2

Coelenterata Frey and Leuckart, 1847

Anthozoa Ehrenberg, 1834

Stylocoenia taurinensis (Michelin, 1842)

Astrocoenia octopartita (Oppenheim, 1901)

Ceratotrochus bodellei Barta-Calmus, 1973

Placosmiliopsis bilobatus (d'Achiardi, 1868)

Desmophyllum castellolense Álvarez-Pérez, 1997

Bryozoa Ehrenberg, 1831

Stenolaemata Borg, 1926

Lichenoporidae indet.
Taxa

Echinodermata Klein, 1734

Crinoidea Miller, 1821

Isselicrinus sp.

\section{$\underline{\text { Ardanatz Sandstone-Ilundain Marl formations }}$}

\section{Gymnolaemata Allman, 1856}

Cupuladriidae indet.

Brachiopoda Duméril, 1806

Rhynchonellata Williams, Carlson, Brunton, Holmer and Popov, 1996

Argyrotheca michelottina (Davidson, 1870)

?Gryphus sp.

Terebratulina tenuistriata (Leymerie, 1846)

Annelida Lamarck, 1809

Polychaeta Grube, 1850

Rotularia spirulaea (Lamarck, 1818)

Polychaeta indet. 1

Polychaeta indet. 2

\section{Mollusca Linnaeus, 1758}

Gastropoda Cuvier, 1795

Leptomaria peresii (d'Orbigny, 1850)

Ptychocerithium johannae (Tournouër in Bouillé, 1873)

Diastoma costellatum (Lamarck, 1804)

Moniquia sp.

Haustator altavillensis (Cossmann and Pissarro, 1902)

Haustator cf. imbricatarius conoideus (Sowerby

$$
\text { J., 1814) }
$$

Sigmesalia $\mathrm{sp.}$

Ampullinidae indet.

? Globularia sp.

Sassia sp.

Cirsotrema (Elegantiscala) cf. bouillei (Tournouër in Bouillé, 1873)

Epitonium sp.

Amaea sp.

Niso sp.

Metula (Celatoconus) sp.

Clavilithes (Clavellofusus) cf. parisiensis Mayer-

Eymar, 1876

Muricidae indet.

Athleta (Volutospina) sp.

Conus sp.

Nihonia aff. transversaria (Lamarck, 1804)

Mathilda sp.

\section{Bivalvia Linnaeus, 1758}

Glycymeris jacquoti (Tournouër in Bouillé, 1873)

Pycnodonte brongniarti (Bronn, 1831)

Hyotissa martinsi (d'Archiac, 1850)

Ostreiodea indet.

\section{Gendulain Formation (Liédena Sandstone Member)}

\section{Ichnotaxa}

Cochlichnus isp.

Palaeophycus tubularis Hall, 1847

Vertical tubes
Gruipeda isp.

Koreanaornis isp.

cf. Koreanaornis
Chordata Haeckel, 1874

Mammalia Linnaeus, 1758

Dugongidae indet.
Chlamys cf. biarritzensis (d'Archiac, 1846)

Chlamys sp.

Spondylus cf. bifrons Münster in Goldfuss, 1840

Spondylus cf. caldesensis Carez 1881

Spondylus planicostatus d'Archiac, 1850

Spondylus sp. cf. Spondylus cisalpinus Brongniart,

1823 - S. nysti d'Archiac, 1846

Spondylus sp.

Dimya pamplonensis (Carez, 1881)

Venericardia junctinova Cossmann, 1897

Chama pellati Boussac, 1911

Chama granulosa d'Archiac, 1850

Scaphopoda Bronn, 1862

Dentalium sp.

Cephalopoda Cuvier, 1797

Nautiloidea indet.

Arthropoda von Siebold, 1848

Maxillopoda Dahl, 1956

Arcoscalpellum sp.

Malacostraca Latreille, 1802

Decapoda indet.

Echinodermata Bruguière, 1791 (ex Klein, 1734)

Crinoidea Miller, 1821

Crinoidea indet.

Echinoidea Leske, 1778

Asteroidea indet.

Echinoidea indet.

Chordata Haeckel, 1874

Chondrichthyes Huxley, 1880

Hexanchus agassizi Cappetta, 1976

Macrorhizodus praecursor (Leriche, 1905)

Woellsteinia kozlovi Adnet, 2006

Anomotodon sp.

Actinopterygii Klein, 1885

Enchodus sp.

Chaetodipterus sp.

\section{Reptilia Laurenti, 1768}

Testudines indet.

Mammalia Linnaeus, 1758

Dugongidae indet.
Leptoptilostipus pyrenaicus Payros, Astibia, Cearreta, Pereda-Suberbiola, Murelaga and Badiola, 2000 cf. Leptoptilostipus 